\title{
Inside the Blackwall Box: Explaining U.S. Marine Salvage Awards
}

Joshua C. Teitelbaum

Georgetown University Law Center, jct48@law.georgetown.edu

Georgetown Business, Economics and Regulatory Law Research Paper No. 12-017

This paper can be downloaded free of charge from:

https://scholarship.law.georgetown.edu/facpub/960

http://ssrn.com/abstract=2060944

22 Sup. Ct. Econ. Rev. 55-121 (2014)

This open-access article is brought to you by the Georgetown Law Library. Posted with permission of the author. Follow this and additional works at: https://scholarship.law.georgetown.edu/facpub

Part of the Admiralty Commons, Law and Economics Commons, and the Law of the Sea Commons 


\title{
Inside the Blackwall Box: Explaining U.S. Marine Salvage Awards
}

\author{
Joshua C. Teitelbaum*
}

Under U.S. maritime law, a salvor of imperiled maritime property on navigable waters is entitled to a monetary award from the owner. When the salvage service is rendered voluntarily in the absence of a contract, the court determines the salvage award according to six factors enumerated by the Supreme Court in The Blackwall, 77 US (10 Wall) 1 (1869). The law, however, does not specify a precise formula or rule for calculating awards on the basis of the Blackwall factors. How do courts turn their findings on the Blackwall factors into salvage awards? This Article addresses this question by examining the reported decisions of U.S. courts in salvage cases from 1799 to 2007. It employs two statistical methods-fractional polynomial regression and regression tree analysis-to make inferences about the mapping from factors to awards implicit in the salvage cases. In addition to presenting the first systematic empirical study of U.S. marine salvage awards, which complements the traditional doctrinal analysis offered by maritime commentators, an important contribution of the Article is that it showcases statistical methods that are well suited to empirical doctrinal analysis but are underutilized in legal scholarship.

* Joshua C. Teitelbaum is a Professor of Law at Georgetown University Law Center. He can be reached at jct48@law.georgetown.edu. The author thanks Conor Larkin for his herculean research assistance. Thanks also to the editor, two reviewers, Andrew Christensen, Kirk Goza, Mischere Kawas, Elizabeth McAleese, and workshop participants at the University of Toronto Faculty of Law and UCLA School of Law.

(C) 2015 by the University of Chicago. All rights reserved. 978-0-226-16666-7/2015/0022-0002\$10.00. 


\section{I N T R O D U C T I O N}

"It was a dark and stormy night. ..."

—Edward Bulwer Lytton ${ }^{1}$

About four o'clock on the morning of August 24, 1867, the British ship Blackwall was discovered on fire in San Francisco harbor. ${ }^{2}$ The officers and crew of the Blackwall, who were unable to subdue the fire, abandoned the ship. "Without speedy assistance the total destruction of the ship and cargo was inevitable." ${ }^{\prime 4}$ The fire department was called. ${ }^{5}$ The chief of the department summoned the aid of the steam tug Goliah, which was docked at one of the harbor's wharves. ${ }^{6}$ The master and crew of the Goliah were roused from their beds and immediately repaired to the wharf. ${ }^{7}$ About six o'clock, the Goliah, with two fire engines and several firemen on board, made fast alongside the burning Blackwall. ${ }^{8}$ Within half an hour, the fire was extinguished and the Goliah was dismissed. ${ }^{9}$

The owner and master of the Goliah brought suit against the Blackwall in the district court in San Francisco, seeking a salvage award. ${ }^{10}$ "Salvage is the compensation allowed to persons by whose assistance a ship or her cargo has been saved, in whole or in part, from impending peril on the sea, or in recovering such property from actual loss, as in cases of shipwreck, derelict, or recapture." ${ }^{11}$ Awards for salvage date back to Byzantium, ${ }^{12}$ and perhaps earlier. ${ }^{13}$

${ }^{1}$ Edward Bulwer Lytton, Paul Clifford 1 (1830).

${ }^{2}$ See The Blackwall, 77 US (10 Wall) 1, 2 (1869).

${ }^{3}$ See id.

${ }^{4}$ Id.

${ }^{5}$ See id.

${ }^{6}$ See The Blackwall, 77 US (10 Wall) at 2.

${ }^{7}$ See id.

${ }^{8}$ See id.

${ }^{9}$ See id at 3.

${ }^{10}$ See The Blackwall, 77 US (10 Wall) at 4.

${ }^{11}$ See id at 12.

${ }^{12}$ See Walter Ashburner, The Rhodian Sea-Law (Clarendon 1909) (translating and discussing salvage provisions under the Byzantine legal code commonly known as the Rhodian Sea Law and dating the code to between 600 and $800 \mathrm{AD}$ ).

${ }^{13}$ See Geoffrey Brice, Maritime Law of Salvage 5-6 (Sweet \& Maxwell 3d ed 1999) ("There is evidence that almost three thousand years ago under the Rhodian maritime code, which was applied in ancient Greece and the Mediterranean, volunteer salvors were held entitled to be rewarded for their services. This principle was adopted in Roman law."). But see Robert D. Benedict, The Historical Position of the Rhodian Law, 
The district court ordered an award of ten thousand dollars, which was affirmed by the circuit court. ${ }^{14}$

The owners of the Blackwall appealed the award to the Supreme Court. ${ }^{15}$ In its opinion, the Court famously enumerated six factors that courts traditionally consider in determining a salvage award. ${ }^{16}$ They are: (1) the labor expended by the salvors in rendering the salvage service; (2) the promptitude, skill, and energy displayed in rendering the service and saving the property; $(3)$ the value of the property employed by the salvors in rendering the service, and the danger to which such property was exposed; (4) the risk incurred by the salvors in securing the property from the impending peril; $(5)$ the value of the property saved; and (6) the degree of danger from which the property was rescued. ${ }^{17}$ Although the Supreme Court agreed with the district court's findings with respect to the facts and circumstances of the salvage operation, and concluded that the award was appropriate for the entire operation, because it was clear that the award reflected the combined services of the Goliah and the fire department (who was not a party to the suit), the Court ordered that the amount of the award be halved to five thousand dollars. ${ }^{18}$

It is "black letter law" that the Blackwall factors are the "main ingredients" in determining the amount of an award for marine salvage. ${ }^{19}$ Courts have discretion in fashioning salvage awards based on their findings with respect to the Blackwall factors, subject to a handful of general principles that guide or delimit their discretion. ${ }^{20}$ However, "no precise formula has been ... described for calculating

18 Yale L J 223 (1909) (rejecting any Rhodian influence on Roman maritime law with the exception of the principle of general average contribution in cases of jettison).

${ }^{14}$ The Blackwall, 77 US (10 Wall) at 4.

${ }^{15}$ See id.

${ }^{16}$ See id at 13-14. See also, for example, Margate Shipping Co v M/V JA Orgeron, 143 F3d 976, 984 (5th Cir 1998) ("The district court traditionally determines the amount of a salvage award according to the six Blackwall factors."); BV Bureau Wijsmuller v United States, 702 F2d 333, 339 (2d Cir 1983) ("The Blackwall factors are those traditionally considered by a court when it makes a salvage award.").

${ }^{17}$ The Blackwall, 77 US (10 Wall) at 13-14. In the interest of brevity, the factors hereinafter will be abridged as follows: (1) the labor expended by the salvors, (2) the skill displayed by the salvors, (3) the danger to the salvors' property, (4) the risk incurred by the salvors, (5) the value of the property saved, and (6) the danger to the property saved.

${ }^{18}$ Id at $14-15$.

${ }^{19}$ Id at 13 ("main ingredients"); HRM, Inc $v$ S/V Venture VII, 972 F Supp 92, 96 (D RI 1997) ("black letter law").

${ }^{20}$ See Part II.B.3. 
salvage awards" on the basis of the Blackwall factors, ${ }^{21}$ a fact that courts have lamented. ${ }^{22}$

How do courts turn their findings on the Blackwall factors into salvage awards? ${ }^{23}$ This Article addresses the question by examining the reported decisions by U.S. courts in salvage cases from the end of the eighteenth century through 2007. It employs two statistical methods-fractional polynomial regression and regression tree analysis-to make inferences about the mapping from factors to awards implicit in the salvage cases. ${ }^{24}$ The former method assumes that the mapping is a smooth function and uses a fractional polynomial to approximate the function. ${ }^{25}$ The latter method assumes a hierarchical and dichotomous decision process and represents the mapping as a binary decision tree. ${ }^{26}$

${ }^{21}$ Allseas Maritime, SA V M/V Mimosa, 812 F2d 243, 246 (5th Cir 1987), rehg denied, 820 F2d 129 (5th Cir 1987). See also cases and other sources cited in note 73.

${ }^{22}$ See, for example, The Maria Josepha, 16 F Cas 733, 733 (CC D SC 1819) ("Questions of salvage are always questions of the most disagreeable kind. In vain the mind looks for relief in its anxiety to do justice by seeking the aid of fixed rules and principles."); The Cherokee, 31 F 167, 172 (D SC 1887) ("No question seems to perplex judges more than the amount to be awarded in salvage cases. . . . No fixed rule existing, we look to general propositions as a guide."). Scholars have noted the judicial angst. See, for example, Steven F. Friedell, ed, 3A Benedict on Admiralty $\S 236$ (Matthew Bender 2011) [hereinafter Benedict on Admiralty] ("There is no set rule or fixed formula by which a salvage award can be determined. Most courts find . . . the determination of the amount of a just and proper award is quite often a very troublesome matter.").

${ }^{23}$ Certain judges and commentators have been rather cynical about the process, suggesting that salvage awards are at best the result of an "intelligent guess" and at worst "simply picked out of the air." The Rescue v The George B. Roberts, 64 F 139, 140 (E D Pa 1894) ("There is no rule by which the value of the services in such cases can be accurately measured. At best the award must be the result of an intelligent guess."); Thomas J. Schoenbaum, Admiralty and Maritime Law § 16-5 (Thomson Reuters 5th ed 2011) ("All too often ... salvage awards are simply picked out of the air."). See also Grant Gilmore and Charles L. Black, The Law of Admiralty 563 (Foundation 2d ed 1975) ("Eventually the trial judge will pull an arbitrary figure out of the air.").

${ }^{24}$ Fractional polynomial regression was introduced by Patrick Royston and Douglas G. Altman, Regression Using Fractional Polynomials of Continuous Covariates: Parsimonious Parametric Modelling, 43 Applied Statistics 429 (1994). The seminal work on regression tree analysis is Leo Breiman, et al, Classification and Regression Trees (Wadsworth 1984).

${ }^{25}$ A fractional polynomial is an extension of a conventional polynomial that allows for non-integer and negative powers. See Patrick Royston and Douglas G. Altman, Approximating Statistical Functions by Using Fractional Polynomial Regression, 46 Statistician 411, 412 (1997).

${ }^{26}$ A binary decision tree (also known as a dichotomous decision tree) is a decision tree with only binary splits. 
Three main conclusions emerge from the empirical analysis. First, the results evidence a positive, statistically significant relationship between the Blackwall factors and the magnitude of the salvage award. In other words, the greater is the order or merit of the salvage operation as measured by the Blackwall factors, the greater is the amount of the salvage award. This finding is expected; indeed, it would be surprising if the results suggested otherwise. This Article, however, is the first to provide large-sample confirmation of this relationship. In addition, the fractional polynomial regression analysis yields an unexpected result: a power law relationship between the award and the value of the property saved (that is, $y=a x^{k}$ for some scaling constant $a$ and power $k$ ). This is noteworthy because of the apparent ubiquity of power laws across a wide range of natural and man-made phenomena, spanning diverse fields such as biology, chemistry, computer science, demography, earth and planetary science, economics and finance, and physics. ${ }^{27}$

Second, the results suggest a ranking of the Blackwall factors in terms of importance. The three most important factors, in descending order of importance, are the value of the property saved (factor 5) (which is the single most important factor, accounting for half of the variation in the salvage awards), the labor expended by the salvors (factor 1 ), and the danger to the property saved (factor 6). Indeed, the regression tree analysis results in a tree that classifies cases using only these factors, and in both the fractional polynomial regression analysis and the regression tree analysis these factors account for nearly all of the collective explanatory power of the Blackwall factors. The three least important factors are the skill displayed by the salvors (factor 2), the danger to the salvors' property (factor 3), and the risk incurred by the salvors (factor 4). Although these factors consistently form the bottom tier, their order within the bottom tier varies across the results. It is noteworthy that the ranking of the Blackwall factors suggested by the empirical analysis is not entirely consistent with the ranking suggested by Erastus Cornelius Benedict, a leading commentator, and endorsed by several courts, including the Court of Appeals for the Second Circuit and the District

\footnotetext{
${ }^{27}$ See, for example, Yogesh Virkar and Aaron Clauset, Power-Law Distributions in Binned Empirical Data, 8 Annals Applied Statistics 89 (2014); Michael P.H. Stumpf and Mason A. Porter, Critical Truths about Power Laws, 335 Science 665 (2012); Xavier Gabaix, Power Laws in Economics and Finance, 1 Ann Rev Econ 255 (2009); Michael Mitzenmacher, A Brief History of Generative Models of Power Law and Lognormal Distributions, 1 Internet Math 226 (2004); M.E.J. Newman, Power Laws, Pareto Distributions and Zip's Law, 46 Contemp Physics 323 (2005).
} 
Court for the Eastern District of Louisiana. ${ }^{28}$ The major differences are that the Benedict ranking does not list the value of the property saved (factor 5) as the most important factor, places the risk incurred by the salvors (factor 4) among the three most important factors, and places the labor expended by the salvors (factor 1) among the bottom three factors. ${ }^{29}$

The third main conclusion of the empirical analysis is that the Blackwall factors explain approximately two-thirds of the variation in the salvage awards. The remaining third is explained by unobserved heterogeneity-that is, variables other than the Blackwall factors, as well as noise. Two potential sources of unobserved heterogeneity-differences across judicial circuits and over time-are explored in the analysis. ${ }^{30}$ Considering the myriad of possible sources of unobserved heterogeneity, the explanatory power of the Blackwall factors is rather striking.

The specific results and conclusions of the empirical analysis aside, an important contribution of this Article is that it represents the first systematic empirical study of U.S. marine salvage awards. That is to say, it offers the first empirical doctrinal analysis of the law governing salvage awards. Prior legal scholarship on salvage awards generally consists of theoretical articles that focus on the equity or efficiency of salvage law, ${ }^{31}$ including with respect to issues such as preventing environmental damage and saving human life. ${ }^{32}$

${ }^{28}$ See Benedict on Admiralty at $\S 237$ (cited in note 22); BV Bureau Wijsmuller, 702 F2d at 339; Margate Shipping Co, 143 F3d at 984-85 (noting that the District Court for the Eastern District of Louisiana adopted the Benedict ranking); Jackson Marine Corp v M/V Blue Fox, 1989 WL 38724, at *3 (ED La 1989). See also notes 78-82 and accompanying text.

${ }^{29}$ More specifically, Benedict reorders the Blackwall factors (in descending order of importance) as follows: factor 6 , factor 5 , factor 4 , factor 2 , factor 3 , and factor 1 . See Benedict on Admiralty at $\$ 237$ (cited in note 22).

${ }^{30}$ See Part IV.A.2.

${ }^{31}$ See, for example, Richard S. Markovits, Background (Fixed-Cost) AvoidanceChoices, Foreground (Variable-Cost) Avoidance-Choices, and the Economically Efficient Approach for Courts to Take in Marine-Salvage Cases: A Positive Analysis and Related Critique of Landes and Posner's Classic Study, 59 Buff L Rev 57 (2011); M.B.W. Sinclair, The Cherry Valley Case: How Wrong Can Economists Be about Salvage?, 31 Tul Marit L J 57 (2006); Paul Hallwood and Thomas J. Miceli, Murky Waters: The Law and Economics of Salvaging Historic Shipwrecks, 35 J Legal Stud 285 (2006); William M. Landes and Richard A. Posner, Salvors, Finders, Good Samaritans, and Other Rescuers: An Economic Study of Law and Altruism, 7 J Legal Stud 83 (1978); Note, Calculating and Allocating Salvage Liability, 99 Harv L Rev 1896 (1986).

${ }^{32}$ See, for example, Thomas L. Nummey, Note, Environmental Salvage Law in the Age of the Tanker, 20 Fordham Envtl L Rev 267 (2009); Jason Parent, No Duty to Save Lives, No Reward for Rescue: Is That Truly the Current State of International Salvage Law?, 12 Ann Surv Intl \& Comp L 87 (2006); Susanne M. Burnstein, Com- 
Other articles that touch on the subject of salvage awards address peculiar topics in salvage law, such as piracy rescue and refusing salvage. ${ }^{33}$ And although some commentators make empirical statements about salvage awards in their textbook treatments of the subject, ${ }^{34}$ these statements are not substantiated with large-sample evidence. ${ }^{35}$ Thus, this Article complements the traditional doctrinal analysis offered by other maritime commentators.

Another important contribution of the Article is that it highlights statistical methods that are well suited to empirical doctrinal analysis but are underutilized in legal scholarship. To my knowledge, the Article is the first study in the legal literature to use fractional polynomial regression for empirical doctrinal analysis. ${ }^{36}$ Perhaps more important, it is the first to juxtapose fractional polynomial regression and regression tree analysis. A key difference between the two methods is that the former takes a parametric approach and

ment, Saving Steel over Souls: The Human Cost of U.S. Salvage Law, 27 Tul Marit L J 307 (2002); Brian F. Binney, Comment, Protecting the Environment with Salvage Law: Risks, Rewards, and the 1989 Salvage Convention, 65 Wash L Rev 639 (1990); Steven F. Friedell, Compensation and Reward for Saving Life at Sea, 77 Mich L Rev 1218 (1979).

${ }^{33}$ Geoffrey Christopher Rapp, Salvage Awards on the Somali Coast: Who Pays for Public and Private Rescue Efforts in Piracy Crises?, 59 Am U L Rev 1399 (2010); David J. Bederman and Brian D. Spielman, Refusing Salvage, 6 Loyola Marit L J 31 (2008).

${ }^{34}$ See, for example, Gerard J. Mangone, United States Admiralty Law 215 (Kluwer 1997) ("Awards may run as high as one-third of the value of the marine property saved ..." "); Gilmore and Black, The Law of Admiralty at 563 (cited in note 23) ("[T]he award will never be for more than half the value of the property. . . In fact, except where the property saved is of trifling value, the award of anywhere near $50 \%$ would be exceptional. Where large values are involved, no recent case awards more than about $20 \%$..." $)$.

${ }^{35}$ Indeed, the only other empirical analysis of U.S. marine salvage awards of which I am aware was conducted by the Court of Appeals for the Fifth Circuit in Margate Shipping Co v M/V JA Orgeron, in which the court "compiled a list of the nine largest salvage awards in comparable high-value, high-order cases since the advent of the Blackwall rule" in order to inform their opinion that the district court's award of 12.5 percent was not excessive. Margate Shipping Co, 143 F3d at 993-95.

${ }^{36} \mathrm{I}$ have found one other study in the legal literature that uses fractional polynomial regression, but it does not use the method for doctrinal analysis. See Chris William Sanchirico, Progressivity and Potential Income: Measuring the Effect of Changing Work Patterns on Income Tax Progressivity, 108 Colum L Rev 1551 (2008). A small handful of studies in the legal literature use classification trees (which are closely related to regression trees) for doctrinal analysis. See, for example, Jonathan P. Kastellec, The Statistical Analysis of Decisions and Legal Rules with Classification Trees, 7 J Empirical Legal Stud 202 (2010); Barton Beebe, An Empirical Study of the Multifactor Tests for Trademark Infringement, 94 Cal L Rev 1581 (2006); Jack F. Williams, Debunking the Myth Engulfing Article 9 Collateral Dispositions, 9 Am Bankr Inst L Rev 703 (2001). 
assumes a smooth functional mapping from the high-dimensional fact space to the low-dimensional outcome space, whereas the latter takes a nonparametric approach and directly partitions the fact space. ${ }^{37}$ Because they take such different approaches, the two methods serve to complement each other and act as mutual robustness checks. In the current study, the two methods yield the same main conclusions, thereby reinforcing each other's results and increasing confidence in the common conclusions.

The remainder of the Article proceeds as follows. Part II provides an overview of U.S. marine salvage law. Part III describes the handcollected data set of salvage cases. It explains the search methods and coding procedures, and presents summary and descriptive statistics. Part IV contains the empirical analysis. It summarizes the statistical methods and presents and discusses the results. Concluding remarks appear in Part V.

\section{I. OVER V IEW OF U.S. MARINE S A L V A G E L A W}

In the United States, marine salvage is governed by principles of general maritime law, which is part of the jus gentium (law of nations). ${ }^{38}$ The U.S. Constitution grants federal courts original jurisdiction in "all Cases of admiralty and maritime jurisdiction," $" 39$ including salvage cases. ${ }^{40}$ By statute, jurisdiction to adjudicate salvage cases lies exclusively with the federal courts. ${ }^{41}$ "Suits for salvage may be in rem against the property saved or the proceeds thereof, or in personam against the party at whose request and for whose ben-

\footnotetext{
${ }^{37}$ Kastellec, 7 J Empirical Legal Stud at 210 (cited in note 36).

${ }^{38}$ See, for example, RMS Titanic, Inc v Haver, 171 F3d 943, 960-61 (4th Cir 1999); Sobonis v Steam Tanker Natl Defender, 298 F Supp 631, 635 (SDNY 1969).

${ }^{39}$ United States Const Art III, $\S 2$.

40 See, for example, Houseman $v$ The North Carolina, 40 US (15 Pet) 40, 48 (1841) ("The points in controversy are, whether salvage is due, and if due, how much? Upon such questions, there can be no doubt of the jurisdiction of a court of admiralty. ... . The admiralty is the only court where such a question can be tried; for what other court, but a court of admiralty, has jurisdiction to try a question of salvage?"); Treasure Salvors, Inc $v$ Unidentified, Wrecked and Abandoned Sailing Vessel, 640 F2d 560, 566 (5th Cir 1981) ("Claims arising out of salvage operation-efforts to rescue or recover ships disabled or abandoned at sea or to retrieve their cargo-are, unquestionably, within the admiralty jurisdiction of the federal courts.").

${ }^{41}$ See 28 USC $§ 1333(1)$ (2012) ("The district courts shall have original jurisdiction, exclusive of the courts of the States, of . . . [a]ny civil case of admiralty or maritime jurisdiction, saving to suitors in all cases all other remedies to which they are otherwise entitled."); Benedict on Admiralty at $\S 14$ (cited at note 22) (explaining that the "saving to suitors" clause of 28 USC $§ 1333(1)$ does not apply to salvage cases).
} 
efit the salvage service was performed."42 An appellate court "will not disturb a salvage award unless it is based on erroneous principles or a misapprehension of the facts or is so grossly excessive or inadequate as to be deemed an abuse of discretion. ${ }^{\prime 43}$

\section{A. Types of Salvage Services}

Salvage services fall into two categories: (1) contract salvage and (2) pure salvage.

1. Contract Salvage. Contract salvage occurs when the owner of property enters into an agreement with a salvor to rescue imperiled assets. ${ }^{44} \mathrm{~A}$ salvage contract may be entered into before any emergency or after the property is already in peril. ${ }^{45} \mathrm{~A}$ court may set aside a salvage contract if either party has taken advantage of an emergency to subject the other to grossly unfair terms. ${ }^{46}$ However, "if the contract has been fairly entered into, with eyes open to all the facts, and no fraud or compulsion exists, the mere fact that it is a hard bargain, or that the service was attended with greater or less difficulty than was anticipated, will not justify setting it aside." 47

${ }^{42}$ The Sabine, 101 US (11 Otto) 384, 386 (1879).

${ }^{43}$ Compania Galeana, SA v Motor Vessel Caribbean Mara, 565 F2d 358, 360 (5th Cir 1978). See also Oelwerke Teutonia v Erlanger and Galinger, 248 US 521 (1919) ("Unless there has been some violation of principle or clear mistake, appeals to this Court concerning the amount of the allowance are not encouraged." |; Benedict on Admiralty at $\S 311$ (cited in note 22 ).

${ }^{44}$ See Benedict on Admiralty at $\S 159$ (cited in note 22).

${ }^{45}$ See Mangone, United States Admiralty Law at 208 (cited in note 34). The most common contract of this sort is the Lloyd's of London Open Form (LOF), although there is no obligation on any party to utilize this document to form a valid contract. See id.

${ }^{46}$ See id; Schoenbaum, Admiralty and Maritime Law at $\S 16-6$ (cited in note 23). See also, Higgins, Inc $v$ The Tri State, 99 F Supp 694, 698 (S D Fla 1951) ("The courts . . . consistently have declared any right to compensation for salvage forfeited or reduced in amount in cases where salvors have taken advantage or attempted to take advantage of the unfortunate by embezzlement of salved property, gross exaggerations of values and dangers, false representations of material matters, or other acts of misconduct."); Magnolia Petroleum Co v National Oil Transport Co, 281 F 336, 340 (S D Tex 1922), affd as modified by $286 \mathrm{~F} 50$ (5th Cir 1923) ("[T]his case is ruled by the general principle . . that there is a clear right in the courts to set aside a salvage agreement, when made on the high seas under compulsion or hardship, morally or otherwise, when such agreement is unconscionable and inequitable..."). This cuts both ways - the salvors could extort a favorable agreement, but the party in peril also could conceal the extent of danger or damage to its own advantage. See Gilmore and Black, The Law of Admiralty at 579 (cited in note 23).

${ }^{47}$ The Elfrida, 172 US 186, 198 (1898). See also The Thornley, 98 F 735, 741-42 (5th Cir 1898); The Lasca, 133 F 1005, 1007 (SDNY 1904). 
2. Pure Salvage. Pure salvage is rendered voluntarily in the absence of a contract. Three elements are necessary for a valid pure salvage claim: (a) a marine peril; (b) service voluntarily rendered when not required as an existing duty or from a special contract; and (c) success in whole or in part, or a contribution to such success. ${ }^{48}$

\section{a. Marine Peril}

Only maritime property can be salvaged. ${ }^{49}$ "Historically maritime property has included vessels; property aboard vessels; property thrown overboard or jetsam; property found freely floating on the sea or flotsam; property on the sea attached to buoys or ligan; and property washed up to shore from the sea or lagan." ${ }^{50}$ In general,

${ }^{48}$ See, for example, The Sabine, 101 US (11 Otto) at 384. Note the difference between salvage and mere towage. See, for example, The Flottbek, 118 F 954, 960 (9th Cir 1902) ("There is a marked and clear distinction between a towage and a salvage service. When a tug is called or taken by a sound vessel as a mere means of saving time, or from considerations of convenience, the service is classed as towage; but if the vessel is disabled, and in need of assistance, it is a salvage service." |; McConnochie $v$ Kerr, 9 F 50, 53 (SDNY 1881) ("A salvage service is a service which is voluntarily rendered to a vessel needing assistance, and is designed to relieve her from some distress or danger either present or to be reasonably apprehended. A towage service is one which is rendered for the mere purpose of expediting her voyage, without reference to any circumstances of danger.").

${ }^{49}$ See generally, for example, Cope v Vallette Dry-Dock Co, 119 US 625 (1887). The saving of life, in contrast to property, does not on its own confer a salvage award. See, for example, Peninsular et Oriental Steam Nav Co v Overseas Oil Carriers, Inc, 553 F2d 830, 835-36 (2d Cir 1977) ("II]t seems to have been admiralty law that rescuing lives at sea, rather than property, merited moral approbation, but no pecuniary reward."); The Plymouth Rock, 9 F 413, 418 (SDNY 1881) ("[B]y the general maritime law ... the saving of human life, disassociated from the saving of property, is not a subject of salvage compensation ..." ); The Emblem, 8 F Cas 611, 612 (D Me 1840) (stating that a court of admiralty has "no authority to allow a reward merely for the saving of life"); Benedict on Admiralty at $\S 24$ (cited in note 22); Schoenbaum, Admiralty and Maritime Law at $\S 16-8$ (cited in note 23); Friedell, 77 Mich L Rev at 1222-23 (cited in note 32). Note, however, that masters of vessels are obliged by statute to "render assistance to any individual found at sea in danger of being lost, so far as the master or individual in charge can do so without serious danger to the master's or individual's vessel or individuals on board." 46 USC § 2304(a)(1) (2012). To discourage disregard for human life in favor of saving property in times of emergency, United States law entitles a salvor of human life, who gives aid following an accident giving rise to salvage, to receive a fair share of the salvage award. See 46 USC $\S 80107$ (a) (2012). In contrast to the law of salvage, the law of finds applies in cases of lost or abandoned property and usually applies to ancient shipwrecks. See generally, for example, Benedict on Admiralty at $\S 158$ (cited in note 22); Schoenbaum, Admiralty and Maritime Law at $\S 16-7$ (cited in note 23); Robert Force, Admiralty and Maritime Law 156-57 (2004); Mangone, United States Admiralty Law at 223-25 (cited in note 34).

${ }^{50}$ Mangone, United States Admiralty Law at 213 (cited in note 34). 
maritime property can include any property with a nexus to traditional maritime activities. ${ }^{51}$

In addition to a maritime nexus, there must be an element of peril. The peril need not be imminent; it only must be reasonably apprehended. ${ }^{52}$ The fact that the peril is later revealed to have been nonexistent or less grave than imagined will not defeat the peril requirement..$^{53}$ In one case, for instance, the "peril" was found to have been entirely imagined by the intoxicated master of the distressed ship; the court noted with some amusement that this was sufficient to sustain a salvage claim. ${ }^{54}$ Moreover, the peril need not be severe; the degree of peril "can affect the amount of the award, but not the establishment of a salvage service." 55

${ }^{51}$ Compare, for example, Lambros Seaplane Base v The Batory, 215 F2d 228, 232 33 (2d Cir 1954) (holding that a seaplane which crashed in navigable waters is subject to salvage), with Provost $v$ Huber, 594 F2d 717, 719-20 (8th Cir 1979) (holding that a house that broke through the ice during transport across a frozen lake is not subject to salvage on account of lack of nexus with traditional maritime activities).

52 See Fort Myers Shell e) Dredging Co v Barge NBC 512, 404 F2d 137, 139 (5th Cir 1968) ("The standard of 'imminent' danger . . . is not the test of marine peril. . . . [T]he standard is not whether the peril is imminent, but rather whether it is 'reasonably to be apprehended.' "), quoting The Leonie O. Louise, 4 F2d 699, 700 (5th Cir 1925). See also, for example, BV Bureau Wijsmuller, 702 F2d 333, 339 (2d Cir 1983); Markakis $v$ S/S Volendam, 486 F Supp 1103, 1106 (SDNY 1980); Phelan v Minges, 170 F Supp 826, 828 (D Mass 1959); The Plymouth Rock, 9 F 413 at 416; The Saragossa, 21 F Cas 425, 426 (SDNY 1867).

${ }^{53}$ See, for example, Petition of Sun Oil Co , 342 F Supp 976, 982 (SDNY 1972), affd sub nom, Sun Oil Co v Govostes, 474 F2d 1048 (2d Cir 1973); The Lowther Castle, $195 \mathrm{~F} \mathrm{604,} 607$ (D NJ 1912) ("The reasonableness of the apprehension is not to be read in the light of what was subsequently ascertained, but of the circumstances at the time when an immediate judgment had to be formed and executed.").

${ }^{54}$ See The Pendragon Castle, 5 F2d 56, 57-58 (2d Cir 1924) ("The picture presented would not better any one's opinion of human nature. ... The undoubted apprehension of danger by the Sapinero's master, which induced him to cover the North Atlantic with calls for aid, was the result of incompetence on his part. Whether that incompetence resulted from drink or disease, or both, we are not sure, but the man was unduly frightened. .. . His apprehension was apparently that he would fill and sink. . . . The Pendragon Castle did remove the master's apprehension, and it did render actual service.").

55 Benedict on Admiralty at $\S 63$ (cited in note 22). See also, for example, The Neshaminy, 228 F 285, 288 (3d Cir 1915) ("The degree of danger is immaterial in considering the nature of the service."); Williamson $v$ The Alphonso, 30 F Cas 4, 5 (D Mass 1853) ("It is strongly urged, that both the peril and the service were too slight to bring the case within the technical definition of salvage. But I am not of this opinion. The relief of property from an impending peril of the sea, by the voluntary exertions of those who are under no legal obligation to render assistance, and the consequent ultimate safety of the property, constitute a case of salvage. It may be a case of more or less merit, according to the degree of peril in which the property was, and the danger and difficulty of relieving it. But these circumstances affect the degree of the service, not its nature."). 


\section{b. Voluntary Service}

The service must be rendered voluntarily and not pursuant to a contract or other legal duty or obligation. ${ }^{56}$ Persons who have a legal duty or obligation to work for the preservation of the imperiled property-including, for instance, the master and crew of a vessel and others engaged in a profession that creates such legal duty or obligation (for example, firefighters) - may not be considered voluntary salvors, except in extraordinary circumstances. ${ }^{57}$ The voluntariness requirement will not be defeated, however, if the service has been ordered by a third party having control of the salvor's movements. ${ }^{58}$ "Moreover, the motive of the salvor is irrelevant; a professional salvor who acts for economic gain is a volunteer as well as a 'good samaritan' salvor." ${ }^{59}$ A putative salvor may start operations on an abandoned vessel without prior authorization-with the hope of later reward. ${ }^{60}$ However, a salvor may not force its services upon an owner or master of a vessel who refuses assistance. ${ }^{61}$

\section{c. Success in Whole or in Part}

Salvage awards are granted only where the service results in success, in whole or in part, in rescuing the imperiled property; failed attempts, however valiant, that result in complete loss of the property will not be rewarded. ${ }^{62}$ Any person who contributes to a success-

${ }^{56}$ See, for example, The Clarita and The Clara, 90 US (23 Wall ) 1, 16-17 (1875); BV Bureau Wijsmuller, 702 F2d at 338-39; Elrod v Luckenbach SS Co, 62 F Supp 935, 936 (SDNY 1945); Benedict on Admiralty at $\S 68$ (cited in note 22).

57 The eligibility of various individuals is detailed in Benedict on Admiralty at $\S \S 48-62$, 69-87 (cited in note 22). See also Schoenbaum, Admiralty and Maritime Law at $\S 16-3$ (cited in note 23 ).

${ }^{58}$ See Sobonis, 298 F Supp at 637.

${ }^{59}$ Schoenbaum, Admiralty and Maritime Law at $\S 16-1$ (cited in note 23). See also, for example, BV Bureau Wijsmuller, 702 F2d at 339 ("Whatever motive impels the true volunteer, be it monetary gain, humanitarian purposes or merely error, it will not detract from the status accorded him by law. Thus professional salvors-who perform their services for monetary gain-may claim salvage awards."), citing Benedict on Admiralty at $\S 68$ (cited in note 22); The Camanche, 75 US (8 Wall ) 448 (1869).

${ }^{60}$ See Mangone, United States Admiralty Law at 209 (cited in note 34); Gilmore and Black, The Law of Admiralty at 535-36 (cited in note 23).

${ }^{61}$ See, for example, Merritt 4 Chapman Derrick «) Wrecking Co v United States, 274 US 611, 613 (1927); Thames Shipyard « Repair Co v United States, 350 F3d 247, 273-74 (1st Cir 2003); Intl Aircraft Recovery, LLC v Unidentified, Wrecked 4$)$ Abandoned Aircraft, 218 F3d 1255, 1262 (11th Cir 2000); The Indian, 159 F 20, 25 (5th Cir 1908); The Choteau, 9 F 211, 211 (CC E D La 1881); Schoenbaum, Admiralty and Maritime Law at $\S 16-1$ (cited in note 23).

62 See, for example, The Sabine, 101 US (11 Otto) at 390 ("Salvors who volunteer go out at their own risk for the chance of earning reward, and if not successful they 
ful salvage operation is entitled to receive a portion of the salvage award, even if the person's efforts alone would not have been sufficient to ensure the success of the operation. ${ }^{63}$ Salvage awards are apportioned among co-salvors according to the "relative participation and risk" of each salvor. ${ }^{64}$

The actions of a salvor that worsen the position of the salved property may reduce the award, preclude it, or result in an award of damages to the salvee. ${ }^{65}$ If the salvage is successful, but the operation causes some damage through ordinary negligence, the salvor is liable and the court will reduce the award accordingly; if, however, the salvor causes damage through "gross negligence or willful misconduct," then the court may deny any award or even award affirmative damages. ${ }^{66}$ Fraud or other dishonest conduct also may deprive a salvor of an award. ${ }^{67}$

are entitled to nothing, the rule being that it is success that gives them a title to salvage remuneration."); The Blackwall, 77 US (10 Wall) 1, 12 (1869); Dorothy I v City of New York, 749 F Supp 2d 50, 62-63 (EDNY 2010); The Myrtle Tunnel, 146 F 324, 327 (D SC 1906) ("Success is an essential ingredient, and however meritorious the service, or benevolent the intentions, or arduous the labor, if it is not attended by beneficial results no reward can be given."); Anderson v The Edam, 13 F 135, 138 (EDNY 1882); The Huntsville, 12 F Cas 996, 1004 (ED SC 1860) ("No matter how daring may be the attempt to save, nor how meritorious the service rendered to the vessel in distress, without success they furnish no claim to reward." |; Benedict on Admiralty at $\S 88$ (cited in note 22); Force, Admiralty and Maritime Law at 156 (cited in note 49).

${ }^{63}$ See, for example, The Flottbek, 118 F 954, 958-60 (9th Cir 1902); The Annie Lord, $251 \mathrm{~F} 157,159$ (D Mass 1917) ("It is not necessary, in order to establish a claim to salvage, that the salvor should actually complete the work of saving the property at risk. It is sufficient if he endeavor to do so, and his efforts have a causal relation to the eventual preservation of it."); The Strathnevis, 76 F 855, 866 (D Wash 1896) ("To earn salvage, success must crown the efforts of the salvors. But, when a vessel has been actually rescued from a situation of peril, all who have contributed at any stage of the rescuing service are entitled to a share of the reward."); Benedict on Admiralty at $\S 91$ (cited in note 22); Gilmore and Black, The Law of Admiralty at 536-37 (cited in note 23$)$.

${ }^{64}$ Schoenbaum, Admiralty and Maritime Law at $\S 16-5$ (cited in note 23). See, for example, Jackson Marine Corp v M/V Blue Fox, 1989 WL 38724 at *5 (ED La 1989); The Lydia, 49 F 666 (EDNY 1892); Benedict on Admiralty at $\S 92$ (cited in note 22); Force, Admiralty and Maritime Law at 158 (cited in note 49).

${ }^{65}$ See Force, Admiralty and Maritime Law at 159-60 (cited in note 49).

${ }^{66}$ See Basic Boats, Inc $v$ United States, 352 F Supp 44, 48-49 (ED Va 1972). See also Schoenbaum, Admiralty and Maritime Law at $\S 16-4$ (cited in note 23). Note that professional salvors are held to a higher standard of care than nonprofessionals. See Mangone, United States Admiralty Law at 219 (cited in note 34).

${ }^{67}$ See Mangone, United States Admiralty Law at 218 (cited in note 34). For a detailed exposition of the law of salvor misconduct, see Benedict on Admiralty at $\S \S 98-129$ (cited in note 22). 


\section{B. Salvage Awards}

1. The Blackwall Factors. "The locus classicus of the elements to be considered by an American Court in determining a salvage award is The Blackwall." ${ }^{68}$ In The Blackwall, the Supreme Court famously wrote:

Courts of admiralty usually consider the following circumstances as the main ingredients in determining the amount of the reward to be decreed for a salvage service: (1.) The labor expended by the salvors in rendering the salvage service. (2.) The promptitude, skill, and energy displayed in rendering the service and saving the property. (3.) The value of the property employed by the salvors in rendering the service, and the danger to which such property was exposed. (4.) The risk incurred by the salvors in securing the property from the impending peril. (5.) The value of the property saved. (6.) The degree of danger from which the property was rescued. ${ }^{69}$

Since the Court's decision in 1869, the six Blackwall factors "have been considered black letter law in setting salvage awards." over, as the Court's use of the word "usually" indicates, federal courts routinely considered the Blackwall factors in deciding salvage cases long before the Court's decision in The Blackwall. ${ }^{71}$

2. No Precise Formula. Although the Blackwall factors supply the "main ingredients" in fashioning a salvage award, ${ }^{72}$ salvage law does not provide the recipe. Indeed, "no precise formula has been . . . described for calculating salvage awards" on the basis of the Blackwall factors. ${ }^{73}$ On the contrary, courts have broad discretion in determin-

${ }^{68}$ Brice, Maritime Law of Salvage at 164 (cited in note 13).

69 The Blackwall, 77 US (10 Wall) at 13-14.

${ }^{70}$ HRM , Inc v S/V Venture VII, 972 F Supp 92, 96 (D RI 1997). In the words of the Court of Appeals for the Ninth Circuit, the Blackwall factors "have weathered the storms of the past century." St Paul Marine Transport Corp v Cerro Sales Corp, 505 F2d 1115, 1120 (9th Cir 1974), quoted in Margate Shipping Co v M/V JA Orgeron, 143 F3d 976, 984 (5th Cir 1998).

${ }^{71}$ Indeed, the data contain 115 cases that pre-date The Blackwall. See Part III.B.

72 The Blackwall, 77 US (10 Wall) at 13.

${ }^{73}$ Allseas Maritime SA v M/V Mimosa, 812 F2d 243, 246 (5th Cir 1987) rehg denied, 820 F2d 129 (5th Cir 1987). See also, for example, Mason $v$ The Blaireau, 6 US (2 Cranch) 240, 267 (1804) ("There is certainly no positive rule, which governs absolutely the rate of salvage."); Virden $v$ The Caroline, 28 F Cas 1219, 1219 (CCD Del 1857) ("There is no rule of law, nor any fixed rule of judicial discretion, by which the compensation can be exactly measured."); Virden, 28 F Cas at 1221 (stating that "there is no certain and definite rule to guide the court" I RMS Titanic, Inc $v$ 
ing salvage awards based on their findings with respect to the Blackwall factors, a fact lamented as early as 1816 by Supreme Court Justice William Johnson:

Questions of salvage are always questions of the most disagreeable kind. In vain the mind looks for relief in its anxiety to do justice by seeking the aid of fixed rules and principles. Such questions are addressed exclusively to discretion, and that discretion must move in a range to which there are no defined limits. ${ }^{74}$

Compounding this anxiety is the tension between offering salvage awards that are sufficient inducement to render aid but not so costly as to encourage those in distress to take unnecessary risks as to avoid salvage. $^{75}$

3. General Principles. The law of salvage offers only a handful of general principles to guide courts and place outer limits on their discretion. One key principle, for example, is that courts are bound to apply all of the Blackwall factors. ${ }^{76}$ However, they may weight or rank the factors as they see fit. ${ }^{77}$

Wrecked and Abandoned Vessel, 742 F Supp 2d 784, 794 (ED Va 2010) ("There is no precise formula for calculating a salvage award." ); Atlantis Marine Towing, Inc $\mathrm{V}$ The M/V Elizabeth, 346 F Supp 2d 1266, 1271 (SD Fla 2004) ("There is no fixed rule for determining the amount of the salvage award."); Atlantis Marine Towing, $346 \mathrm{~F}$ Supp $2 \mathrm{~d}$ at 1275 ("As indicated above, the Court is mindful that there is no precise mathematical formula to determine the amount of a proper salvage award."); New Bedford Marine Rescue, Inc, v Cape Jeweler's Inc, 240 F Supp 2d 101, 115 (D Mass 2003) (stating that "there is no precise formula utilized by courts to determine the salvage award"); Trico Marine Operators, Inc v Dow Chemical Co, 809 F Supp 440, 441 (ED La 1992) ("There is no precise formula for determining an appropriate salvage award . . "); Markakis V S/S Veendam, 1981 AMC 2275, 2277 (SDNY 1981) (stating that "there is no fixed formula for computing a salvage award"); Franklin Sears V SS American Producer, 1972 AMC 1647, 1654 (ND Cal 1972) (stating that "there is no precise formula for computing salvage"); Nicholas E Vernicos Shipping Co v United States, 223 F Supp 116, 120 (SDNY 1963), modified, 349 F2d 465 (2d Cir 1965) ("A much more difficult question is the amount of the [salvage] award. . . There is no precise formula for computation."); The Waterloo, 29 F Cas 399, 402 (SDNY 1830) ("The want of fixed principles of compensation is the source of serious perplexity to courts and of uncertainty to parties in interest.").

${ }^{74}$ The Maria Josepha, 16 F Cas 733, 734 (CC D SC 1819). See also, for example, sources cited note 22 .

75 See, for example, American Petroleum Co $v$ The Veendam, 46 F 489, 494-95 (SDNY 1891) (discussing competing interests in striking a balance).

${ }^{76}$ See Margate Shipping Co, 143 F3d at 990.

${ }^{77}$ See, for example, Force, Admiralty and Maritime Law at 158 (cited in note 49). 
In BV Bureau Wijsmuller $v$ United States, the Court of Appeals for the Second Circuit adopted the following ranking (in descending order of importance): (i) the danger to the property saved (factor 6); (ii) the value of the property saved (factor 5); (iii) the risk incurred by the salvors (factor 4); (iv) the skill displayed by the salvors (factor 2); (v) the danger to the salvors' property (factor 3); and (vi) the labor expended by the salvors (factor 1). ${ }^{78}$ This ranking was suggested by a leading commentator, ${ }^{79}$ and has since been endorsed by several other courts, including the District Court for the Eastern District of Louisiana. ${ }^{80}$ By contrast, the Court of Appeals for the Third Circuit pointed out that various courts and commentators have listed the Blackwall factors in different orders and then stated:

The conclusion to be deduced from these facts is that in considering the various ingredients which enter into the amount of salvage to be awarded, there is no special significance to be attached to the order in which they are mentioned. The amount of the award, determined by emphasis being laid sometimes on one ingredient and sometimes on another, "is largely a matter of fact and discretion, which cannot be reduced to precise rules, but depends upon a consideration of all the circumstances of each case." ... In mentioning the ingredients above we did not intend to declare a rule of law as to which ingredient was entitled to most consideration in any particular case. The order in which they are mentioned is without significance. ${ }^{81}$

In general, there is no consensus on the order of importance of the Blackwall factors. ${ }^{82}$

A second key principle is that the amount of the award may not exceed the value of the property saved. ${ }^{83}$ For a relatively brief period

${ }^{78}$ BV Bureau Wijsmuller, $702 \mathrm{~F} 2 \mathrm{~d}$ at 339.

${ }^{79}$ See Benedict on Admiralty at $\S 237$ (cited in note 22).

${ }^{80}$ See Margate Shipping Co, 143 F3d at 984-88; Jackson Marine Corp, 1989 WL 38724 at ${ }^{*}$. In Margate, the Court of Appeals for the Fifth Circuit stated that the value of the property saved (factor 5) is "clearly one of the most important of the Blackwall factors" and that when the danger to the property saved (factor 6) is high ("essentially ... a 100 percent chance of total loss") the value of the property saved "takes on added significance." 143 F3d at 987-88 \& n 15.

${ }^{81}$ Atlantic Refining Co v Merritt e) Chapman Derrick e) Wrecking Co, 300 F 901, 907 (3d Cir 1924), quoting The Connemara, 108 US 353, 359 (1883), and citing Peisch $v$ Ware, 4 US (4 Cranch ) 347, 364 (1808).

${ }^{82} 67 \mathrm{~B}$ Am Jur 2d Salvage $§ 70$ (2010).

${ }^{83}$ See, for example, The Sabine, 101 US (11 Otto) at 390; Allseas Maritime, 812 F2d at 246; Trico Marine Operators, 809 F Supp at 441; Schoenbaum, Admiralty and Maritime Law at $\S 16-5$ (cited in note 23); Brice, Maritime Law of Salvage at 151 (cited in note 13); Gilmore and Black, The Law of Admiralty at 563 (cited in note 23). 
in the early history of American salvage law, awards were made on the basis of a moiety or other fixed percentage of the value of the property saved in cases of derelict property ${ }^{84}$ In these cases, the principle was self-actualizing. However, "[i]t is now generally agreed that salvage awards should not be made on the basis of a moiety or other fixed percentage. ${ }^{\prime 85}$ Nevertheless, courts continue to adhere to the principle that the value of the property saved is the "ceiling for the maximum allowable total award." ${ }^{\prime 86}$ Reference to the salved value helps courts ensure that the interests of the salvees are protected. ${ }^{87}$

A third, noteworthy principle is that courts do not view salvage awards "merely as pay, on the principle of a quantum meruit, or as a remuneration pro opere et labore, but as a reward given for perilous services, voluntarily rendered, and as an inducement to seamen and others to embark in such undertakings to save life and property. ${ }^{\prime \prime 8}$

4. Recent Developments. In 1992, courts in two cases added a seventh factor to the Blackwall list (though each added a different seventh factor). In Columbus-America Discovery Group v Atlantic Mutual Insurance Co, ${ }^{89}$ the Court of Appeals for the Fourth Circuit added the following factor, to be applied in cases of salvage of historically valuable shipwrecks: "the degree to which the salvors have worked to protect the historical and archeological value of the wreck and items salved." ${ }^{\prime \prime 0}$ In Trico Marine Operators, Inc $v$ Dow Chemical Co, ${ }^{91}$ the District Court for the Eastern District of Louisiana added the following factor: the "skill and efforts of the salvors

${ }^{84}$ See Benedict on Admiralty at $\S 258$ (cited in note 22). See also, for example, Mason v Blaireau, 6 US (2 Cranch) 240 (1804); Warder v La Belle Creole, 29 F Cas 15 (D Pa 1792).

${ }^{85}$ Benedict on Admiralty at $\S 240$ (cited in note 22). See also, for example, Sears $V$ SS American Producer, 1972 AMC 1647, 1654 (N D Cal 1972); The Egypt, 17 F 359, 367-68 (ED Va 1883).

${ }^{86}$ Ocean Servs Towing $\uplus$ Salvage, Inc v Brown, 810 F Supp 1258, 1264 (SD Fla 1993)

${ }^{87}$ See, for example, Hennessey $v$ The Versailles, 11 F Cas 1128, 1131 (D Mass 1853) (stating that the large salved value in that situation gave the court the opportunity to offer a large award "without casting a heavy burden upon an amount of property too small to be adequate to bear it").

${ }^{88}$ The Blackwall, 77 US (10 Wall) at 1, 14. See also, for example, BV Bureau Wijsmuller, 702 F2d at 338 (2d Cir 1983).

${ }^{89}$ Columbus-America Discovery Group v Atlantic Mutual Insurance Co, 974 F2d 450 (4th Cir 1992).

${ }^{90}$ Id at 468; see also RMS Titanic, 742 F Supp 2d at 794. 19921 .

1 Trico Marine Operators, Inc v Dow Chemical Co, 809 F Supp 440 (ED La 
in preventing or minimizing damage to the environment. ${ }^{\prime 92}$ In addition, the court stated in dicta that an exception to the principle that the amount of the award may not exceed the value of the property saved should be made "where the value of the property saved is inadequate to compensate salvors for their efforts in protecting the environment." 93 The Court of Appeals for the Fifth Circuit, however, later stated that "the extra-Blackwall environmental protection factor announced in Trico . . . has never been endorsed by this court." 194

\section{DESCRIPTION OF THE DATA}

\section{A. Search Methods and Coding Procedures}

The data comprise 684 pure salvage cases from 1799 to $2007 .{ }^{95}$ The cases were identified using a number of search methods. Together, the searches were designed to locate all reported cases from U.S. federal courts decided on or before December 31, 2007, that apply the Blackwall factors to determine awards for pure salvage.

The first search methods were "KeyCiting" and "Shepardizing" The Blackwall in Westlaw and LexisNexis, respectively. The second search method was performing keyword searches in three databases: Westlaw's Federal Maritime Law-Cases (FMRT-CS); Lexis's Admiralty Cases, Federal and State (MEGA); and American Maritime Cases (AMC), which is available on Westlaw and Lexis. ${ }^{96}$ The third search method was consulting the salvage digests in West's federal

${ }^{92}$ Id at 443. A similar factor is listed in Article 13 of the 1989 International Convention on Salvage (which was ratified by the U.S. Senate and came into effect on July 14, 1996). See Schoenbaum, Admiralty and Maritime Law at $\S 16-5$ (cited in note 23). As was the case with the 1910 Convention for the Unification of Certain Rules of Law relating to Assistance and Salvage at Sea, however, U.S. courts have largely overlooked or ignored the 1989 Convention, and virtually all salvage cases since 1996 have been decided without applying or even mentioning the 1989 Convention. See Martin Davies, Whatever Happened to the Salvage Convention 1989?, 39 J Marit L \& Comm 463, 463-64 (2008).

${ }_{93}$ Trico Marine Operators, 809 F Supp at 444. Article 14 of the 1989 Salvage Convention provides for "special compensation" for a salvor who prevents or minimizes environmental damage. See Schoenbaum, Admiralty and Maritime Law at $\S 16-5$ (cited in note 23). But, again, U.S. courts have largely overlooked or ignored the 1989 Convention. See Davies, 39 J Marit L \& Comm at 463-64 (cited in note 92).

${ }^{94}$ Margate Shipping Co, 143 F3d at 988-89.

95 The data are available at the Georgetown Law Dataverse.

${ }^{96}$ Westlaw's FMRT-CS database contains maritime cases from U.S. federal courts. Coverage begins with 1789. Lexis's MEGA database contains maritime cases from U.S. federal and state courts. Coverage for federal courts begins with 1789. The AMC 
digest. ${ }^{97}$ The fourth search method was consulting the salvage award tables in the quinquennial digests of American Maritime Cases. ${ }^{98}$ The fifth search method was consulting leading treatises on admiralty and maritime law. ${ }^{99}$ The sixth search method was consulting early American digests and reporters. ${ }^{100}$ The final search method was examining each case, however identified, for two purposes: (i) to find additional cases cited therewithin and (ii) to cull cases that, on closer inspection, did not apply the Blackwall factors to determine an award for pure salvage.

These searches yielded 881 pure salvage cases from 1779 to 2007. ${ }^{101}$ Of these cases, 197 were excluded from the final data set because they were missing either a clear statement of the salvage award or clear findings with respect to one or more of the Blackwall factors. ${ }^{102}$ Thus, the final data set includes 684 cases from 1799 to 2007.

database contains significant maritime decisions rendered by U.S. federal and state courts. Coverage begins with 1923.

${ }^{97} 57$ West's Federal Practice Digest (4th ed 1998).

${ }^{98}$ Five Year Index-Digest of American Maritime Cases vols 1-17 (1923-2007).

${ }^{99}$ Schoenbaum, Admiralty and Maritime Law (cited in note 23); Benedict on Admiralty (cited in note 22); Brice, Maritime Law of Salvage (cited at note 13); Mangone, United States Admiralty Law (cited in note 34); Gilmore and Black, The Law of Admiralty (cited at note 23).

${ }^{100}$ Austin Abbott, Abbott's Cyclopedic Digest of All the Decisions of All the Courts of New York from the Earliest Time to the Year 1900 (1901); Henry B. Brown, Reports of Admiralty and Revenue Cases, Argued and Determined in the Circuit and District Courts of the United States, for the Western Lake and River Districts (1876); John S. Newberry, Reports of Admiralty Cases, Argued and Adjudged in the District Courts of the United States, for the District of Michigan, Northern District of Ohio, Southern District of Ohio, Western District of Pennsylvania, Northern District of Illinois, District of Missouri, and Eastern District of Louisiana, from 1842 to 1857 (1857); Samuel Blatchford and Francis Howland, Reports of Cases Argued and Determined in the District Court of the United States for the Southern District of New York (1855); Thomas Bee, Reports of Cases Adjudged in the District Court of South Carolina (1810) (includes an appendix that also reports cases from the Admiralty Court of Pennsylvania); Richard Peters, Admiralty Decisions in the District Court of the United States, for the Pennsylvania District (1807).

${ }^{101}$ The cases are listed in the Appendix. A case is listed more than once if it makes more than one award.

${ }^{102}$ More specifically, sixty-four cases were excluded because they were missing a clear statement of the salvage award. After excluding these cases, another 133 were excluded because they were missing clear findings with respect to one or more of the Blackwall factors. There appears to be no systematic pattern to the missing factors. Among all 881 cases, each factor has a missing rate between 10.3 and 14.0 percent, and among the 817 cases with clear statements of the salvage award, each factor has a missing rate between 6.9 and 9.5 percent. 
For each case, the data record the date of the decision, ${ }^{103}$ the court, ${ }^{104}$ the award (in 1980 U.S. dollars), ${ }^{105}$ the court's finding on each Blackwall factor, and an indicator for whether the award was determined with reference to a moiety or other fixed percentage. ${ }^{106}$ The data also include indicators for whether the case pre-dates The Blackwall or post-dates 1992 (the year in which Columbus-America and Trico Marine were decided) ${ }^{107}$ and the federal judicial circuit to which the court belongs.

The Blackwall factors (other than the value of the property saved) are coded as binary variables (high $=1$ or low $=0$ ), for two reasons. The first reason is that courts routinely characterize salvage operations as "high order" or "low order."108 The second reason is that binary coding minimizes subjectivity and, therefore, disagreement or error. The value of the property saved is recorded in 1980 U.S. dollars.

The following procedures were followed in coding the cases. After receiving instructions from me, a research assistant read every case and hand coded every variable. In addition, I met regularly with the research assistant to review his progress and discuss any coding issues or questions. Finally, I audited his work by independently reading and shadow coding 15 percent of the cases. Our disagreement rate was zero with respect to the awards and less than 1 percent with respect to the Blackwall factors.

\section{B. Summary and Descriptive Statistics}

The 684 cases in the final data set were decided between March 1799 and December 2007. One hundred fifteen cases (16.8 percent) predate The Blackwall and fifteen cases (2.2 percent) post-date 1992. The remaining 554 cases (81.0 percent) were decided between 1870 and 1992.

${ }^{103}$ The data record the full date (day, month, and year) for 635 cases. For forty-five cases, the data record only the month and year. For four cases, the data record only the year. Most of the date information was collected from the reported decisions. Some date information, however, was collected from other sources with the assistance of a reference librarian at Georgetown Law Library and staff at regional branches of the U.S. National Archives.

${ }^{104}$ The court is the court of final adjudication, and the data record the award and findings of fact as determined by the court of final adjudication.

${ }^{105}$ Adjustments for inflation were made using Tom's Inflation Calculator, available at http://www.halfhill.com/inflation.html.

${ }^{106}$ See Part II.B.3.

${ }^{107}$ See Part II.B.4.

${ }^{108}$ See, for example, Benedict on Admiralty at $\S 278$ (cited in note 22). 
Table 1 displays summary statistics for the seven primary variables (the salvage award and the six Blackwall factors). The salvage awards range from $\$ 240$ to $\$ 1,866,000$, with a mean award of $\$ 74,000$. The value of the property saved (factor 5) ranges from $\$ 1,200$ to $\$ 42,133,000$, with a mean value of $\$ 1,386,000$. The labor expended by the salvors (factor 1) and the skill displayed by the salvors (factor 2) were high in 39 percent and 44 percent of the cases, respectively. The danger to the salvors' property (factor 3) and the risk incurred by the salvors (factor 4) were high in 28 percent and 18 percent of the cases, respectively. The danger to the property saved (factor 6) was high in 51 percent of the cases.

Though not shown in Table 1, it is also noteworthy that: (i) the award percentage (the salvage award expressed as a fraction of the value of the property saved) ranges from less than 1 percent to 85 percent, with a mean of 14 percent; and (ii) the salvage award was determined with reference to a moiety or other fixed percentage in 10 percent of the cases. The fact that the award percentage never exceeds 100 percent confirms that courts adhere to the principle that the amount of the award may not exceed the value of the property saved.

Figure 1 presents a scatter plot of the award percentage and the value of the property saved. It shows an "L-shaped" relationship—as

Table 1. Summary Statistics

\begin{tabular}{llcccc}
\hline & Variable & Mean & $\begin{array}{c}\text { Standard } \\
\text { Deviation }\end{array}$ & Minimum & Maximum \\
\hline award & $\begin{array}{l}\text { Salvage award } \\
\text { Labor expended by } \\
\text { salvors } \\
\text { factor1 }\end{array}$ & 74.44 & 153.35 & 0.24 & $1,865.62$ \\
& $\begin{array}{c}\text { Skill displayed by } \\
\text { salvors }\end{array}$ & 0.39 & 0.49 & 0 & 1 \\
factor2 & $\begin{array}{c}\text { Danger to salvors' } \\
\text { property }\end{array}$ & 0.44 & 0.50 & 0 & 1 \\
factor3 & $\begin{array}{l}\text { Risk to salvors } \\
\text { factor4 }\end{array}$ & 0.18 & 0.45 & 0 & 1 \\
factor5 & $\begin{array}{c}\text { Value of property } \\
\text { saved }\end{array}$ & $1,385.71$ & $2,913.98$ & 1.20 & $42,133.47$ \\
factor6 & $\begin{array}{c}\text { Danger to property } \\
\text { saved }\end{array}$ & 0.51 & 0.50 & 0 & 1 \\
\hline
\end{tabular}

Notes: 684 cases from 1799 to 2007. Variables award and factor5 in thousands of 1980 U.S. dollars. 


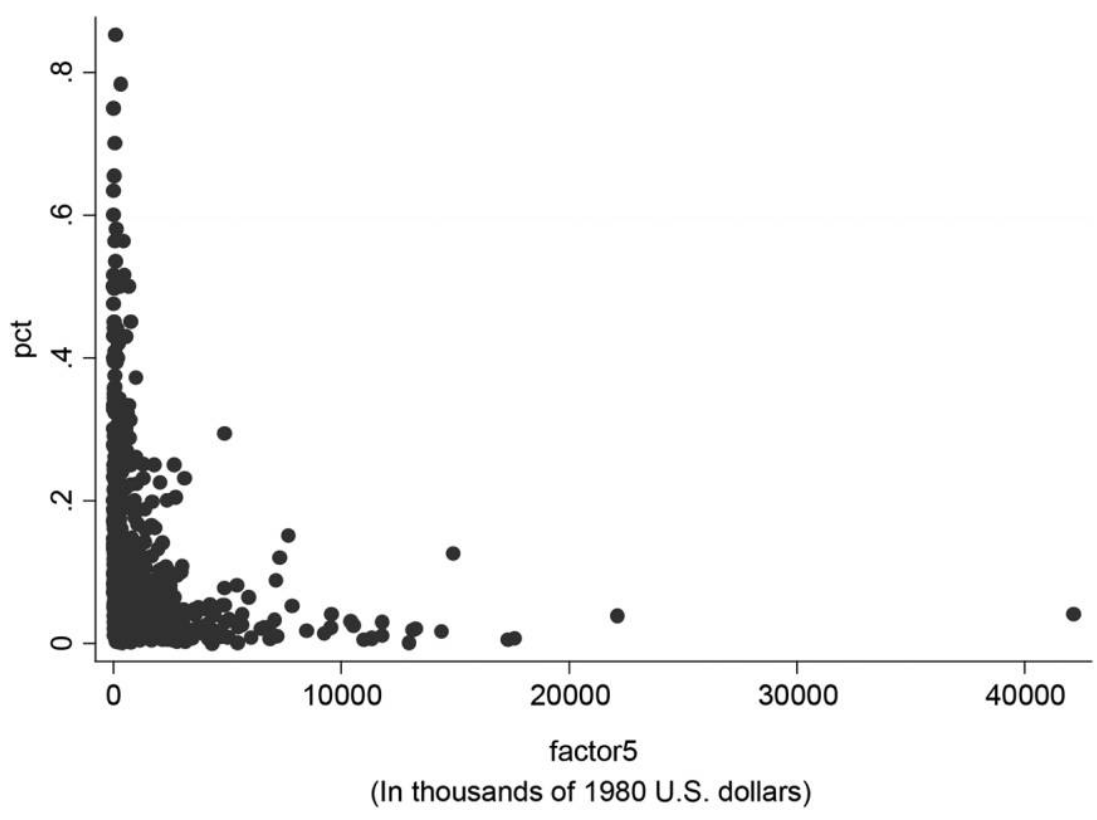

Figure 1. Scatter Plot of Award Percentage and Value of Property Saved

the value of the property saved increases, the maximum award percentage decreases at a decreasing rate. This is the first hint of a power law relationship between the award and value of the property saved. After all, if $y=a x^{k}$ with $a>0$ and $k \in(0,1)$, then $y / x=a x^{k-1}$ exhibits such an L-shape.

Table 2 displays the mean salvage award conditional on different findings on the Blackwall factors. As expected, for each Blackwall factor, the mean award when the factor is "low" is smaller than the mean award when the factor is "high," and each pair of conditional means lies on either side of the unconditional mean. For instance, the mean award for cases in which the labor expended by the salvors was low is $\$ 36,000$, the mean award for cases in which the labor expended by the salvors was high is $\$ 134,000$, and the unconditional mean award for all cases is $\$ 74,000$. The patterns displayed in the table evidence a positive relationship between each Blackwall factor and the salvage award.

Table 3 presents the correlation matrix for the seven primary variables. Predictably, the value of the property saved (factor 5) and the award are highly correlated $(0.60)$, as are the danger to the salvors' property (factor 3 ) and the risk incurred by the salvors (factor 4) (0.44). None of the other pairwise correlations is greater than 0.31, 
Table 2. Conditional Salvage Awards

\begin{tabular}{|c|c|c|}
\hline Variable & Cases & Mean \\
\hline award & 684 & 74.44 \\
\hline award if factor $1=$ low & 415 & 35.67 \\
\hline award if factor1 = high & 269 & 134.24 \\
\hline award if factor2 $=10 \mathrm{w}$ & 382 & 51.07 \\
\hline award if factor2 $=$ high & 302 & 103.99 \\
\hline award if factor3 $=10 \mathrm{w}$ & 498 & 57.57 \\
\hline award if factor $3=$ high & 186 & 119.60 \\
\hline award if factor4 $=10 \mathrm{w}$ & 559 & 58.41 \\
\hline award if factor4 = high & 125 & 146.09 \\
\hline $\begin{array}{l}\text { award if factor5 is belov } \\
\text { average }\end{array}$ & 504 & 37.98 \\
\hline $\begin{array}{l}\text { award if factor } 5 \text { is above } \\
\text { average }\end{array}$ & 180 & 176.50 \\
\hline award if factor6 $=10 \mathrm{w}$ & 337 & 45.18 \\
\hline award if factor6 $=$ high & 347 & 102.85 \\
\hline
\end{tabular}

Notes: Awards in thousands of 1980 U.S. dollars. For each factor, the difference between the mean conditional awards is significant at the 1 percent level.

and for three factor pairs (factor3-factor5, factor4-factor5, and factor5factor6) the correlation is not statistically significant.

Table 4 displays the number and frequency of cases for all thirtytwo possible combinations of the five dichotomous Blackwall factors. The most frequent combination (158 cases or 23.1 percent) has findings of "low" for each factor. The combination with findings of "high" for each factor is fifth most frequent (forty-three cases or 6.3 percent). Of the thirty other possible combinations, fourteen occur in ten or more cases while sixteen occur in fewer than ten cases.

Table 5 breaks down the cases by the federal judicial circuit of the court that decided the case. ${ }^{109}$ It also lists the individual courts that decided at least ten cases. Courts in the Second Circuit decided the most cases (236 cases or 34.5 percent), while courts in the

${ }^{109}$ As stated in note 104, this is the court of final adjudication. Of the 684 cases, 545 (79.7 percent) were decided by district courts, 134 (19.6 percent) were decided by circuit courts, and five (0.7 percent) were decided by the Supreme Court. 
Table 3. Correlation Matrix for Primary Variables

\begin{tabular}{|c|c|c|c|c|c|c|c|}
\hline & award & factor1 & factor2 & factor3 & factor4 & factor5 & factorb \\
\hline award & 1.00 & & & & & & \\
\hline \multirow[t]{2}{*}{ factor1 } & 0.31 & 1.00 & & & & & \\
\hline & $(0.00)$ & & & & & & \\
\hline \multirow[t]{2}{*}{ factor2 } & 0.17 & 0.18 & 1.00 & & & & \\
\hline & $(0.00)$ & $(0.00)$ & & & & & \\
\hline \multirow[t]{2}{*}{ factor3 } & 0.18 & 0.25 & 0.20 & 1.00 & & & \\
\hline & $(0.00)$ & $(0.00)$ & $(0.00)$ & & & & \\
\hline \multirow[t]{2}{*}{ factor4 } & 0.22 & 0.29 & 0.29 & 0.44 & 1.00 & & \\
\hline & $(0.00)$ & $(0.00)$ & $(0.00)$ & $(0.00)$ & & & \\
\hline \multirow[t]{2}{*}{ factor5 } & 0.60 & 0.10 & 0.12 & 0.01 & 0.02 & 1.00 & \\
\hline & $(0.00)$ & $(0.01)$ & $(0.00)$ & $(0.84)$ & $(0.64)$ & & \\
\hline \multirow[t]{2}{*}{ factor6 } & 0.19 & 0.18 & 0.24 & 0.29 & 0.22 & 0.01 & 1.00 \\
\hline & $(0.00)$ & $(0.00)$ & $(0.00)$ & $(0.00)$ & $(0.00)$ & $(0.74)$ & \\
\hline
\end{tabular}

Note: Numbers in parentheses are p-values.

Table 4. Factor Combinations

\begin{tabular}{lcccccc}
\hline \multicolumn{5}{c}{ Combination } & & \\
factor1 & factor2 & factor3 & factor4 & factor6 & Cases & Percentage \\
\hline 0 & 0 & 0 & 0 & 0 & 158 & 23.1 \\
1 & 0 & 0 & 0 & 0 & 40 & 5.8 \\
0 & 1 & 0 & 0 & 0 & 51 & 7.5 \\
0 & 0 & 1 & 0 & 0 & 9 & 1.3 \\
0 & 0 & 0 & 1 & 0 & 1 & 0.1 \\
0 & 0 & 0 & 0 & 1 & 60 & 8.8 \\
1 & 1 & 0 & 0 & 0 & 22 & 3.2 \\
1 & 0 & 1 & 0 & 0 & 8 & 1.2 \\
1 & 0 & 0 & 1 & 0 & 7 & 1.0 \\
1 & 0 & 0 & 0 & 1 & 36 & 5.3 \\
0 & 1 & 1 & 0 & 0 & 6 & 0.9
\end{tabular}


Table 4. (continued)

\begin{tabular}{|c|c|c|c|c|c|c|}
\hline \multicolumn{5}{|c|}{ Combination } & \multirow[b]{2}{*}{ Cases } & \multirow[b]{2}{*}{ Percentag } \\
\hline factor1 & factor2 & factor3 & factor4 & factor6 & & \\
\hline 0 & 1 & 0 & 1 & 0 & 3 & 0.4 \\
\hline 0 & 1 & 0 & 0 & 1 & 60 & 8.8 \\
\hline 0 & 0 & 1 & 1 & 0 & 5 & 0.7 \\
\hline 0 & 0 & 1 & 0 & 1 & 20 & 2.9 \\
\hline 0 & 0 & 0 & 1 & 1 & 4 & 0.6 \\
\hline 1 & 1 & 1 & 0 & 0 & 10 & 1.5 \\
\hline 1 & 1 & 0 & 1 & 0 & 8 & 1.2 \\
\hline 1 & 1 & 0 & 0 & 1 & 32 & 4.7 \\
\hline 1 & 0 & 1 & 1 & 0 & 1 & 0.1 \\
\hline 1 & 0 & 1 & 0 & 1 & 19 & 2.8 \\
\hline 1 & 0 & 0 & 1 & 1 & 2 & 0.3 \\
\hline 0 & 1 & 1 & 1 & 0 & 2 & 0.3 \\
\hline 0 & 1 & 1 & 0 & 1 & 12 & 1.8 \\
\hline 0 & 1 & 0 & 1 & 1 & 3 & 0.4 \\
\hline 0 & 0 & 1 & 1 & 1 & 4 & 0.6 \\
\hline 1 & 1 & 1 & 1 & 0 & 6 & 0.9 \\
\hline 1 & 1 & 0 & 1 & 1 & 11 & 1.6 \\
\hline 1 & 1 & 1 & 0 & 1 & 16 & 2.3 \\
\hline 1 & 0 & 1 & 1 & 1 & 8 & 1.2 \\
\hline 0 & 1 & 1 & 1 & 1 & 17 & 2.5 \\
\hline \multirow[t]{2}{*}{1} & 1 & 1 & 1 & 1 & 43 & 6.3 \\
\hline & & & & Total & 684 & 100.0 \\
\hline
\end{tabular}

Ninth, Eleventh, Fourth, First, and Fifth Circuits decided eightyseven, eighty-four, seventy-seven, seventy-four, and sixty-two cases, respectively. The remaining sixty-four cases were decided by courts in the other judicial circuits and by the Supreme Court. The two circuit courts that decided the most cases are the Court of Appeals for the Fifth Circuit (twenty-four cases or 3.5 percent) and the Court of Appeals for the Second Circuit (twenty-three cases or 3.4 percent). The five district courts that decided the most cases are the 
Table 5. Courts

\begin{tabular}{|c|c|c|}
\hline Judicial Circuit & Cases & Percentage \\
\hline First & 74 & 10.8 \\
\hline Second & 236 & 34.5 \\
\hline Third & 34 & 5.0 \\
\hline Fourth & 77 & 11.3 \\
\hline Fifth & 62 & 9.1 \\
\hline Sixth & 10 & 1.5 \\
\hline Seventh & 8 & 1.2 \\
\hline Ninth & 87 & 12.7 \\
\hline Eleventh & 84 & 12.3 \\
\hline Other judicial circuits & 7 & 1.0 \\
\hline Supreme Court & 5 & 0.7 \\
\hline Total & 684 & 100.0 \\
\hline Court & Cases & Percentage \\
\hline 2d Cir & 23 & 3.4 \\
\hline 5th Cir & 24 & 3.5 \\
\hline 9th Cir & 12 & 1.8 \\
\hline CC SD NY & 11 & 1.6 \\
\hline D Mass & 40 & 5.8 \\
\hline $\mathrm{D} \mathrm{Me}$ & 14 & 2.0 \\
\hline D Or & 10 & 1.5 \\
\hline $\mathrm{D} \mathrm{NJ}$ & 11 & 1.6 \\
\hline D SC & 15 & 2.2 \\
\hline ED La & 15 & 2.2 \\
\hline $\mathrm{ED} \mathrm{Pa}$ & 15 & 2.2 \\
\hline ED Va & 27 & 3.9 \\
\hline EDNY & 81 & 11.8 \\
\hline ND Cal & 20 & 2.9 \\
\hline SD Fla & 53 & 7.7 \\
\hline SDNY & 95 & 13.9 \\
\hline WD Wash & 18 & 2.6 \\
\hline Other courts & 200 & 29.2 \\
\hline Total & 684 & 100.0 \\
\hline
\end{tabular}

Note: Courts not listed decided fewer than ten cases. 


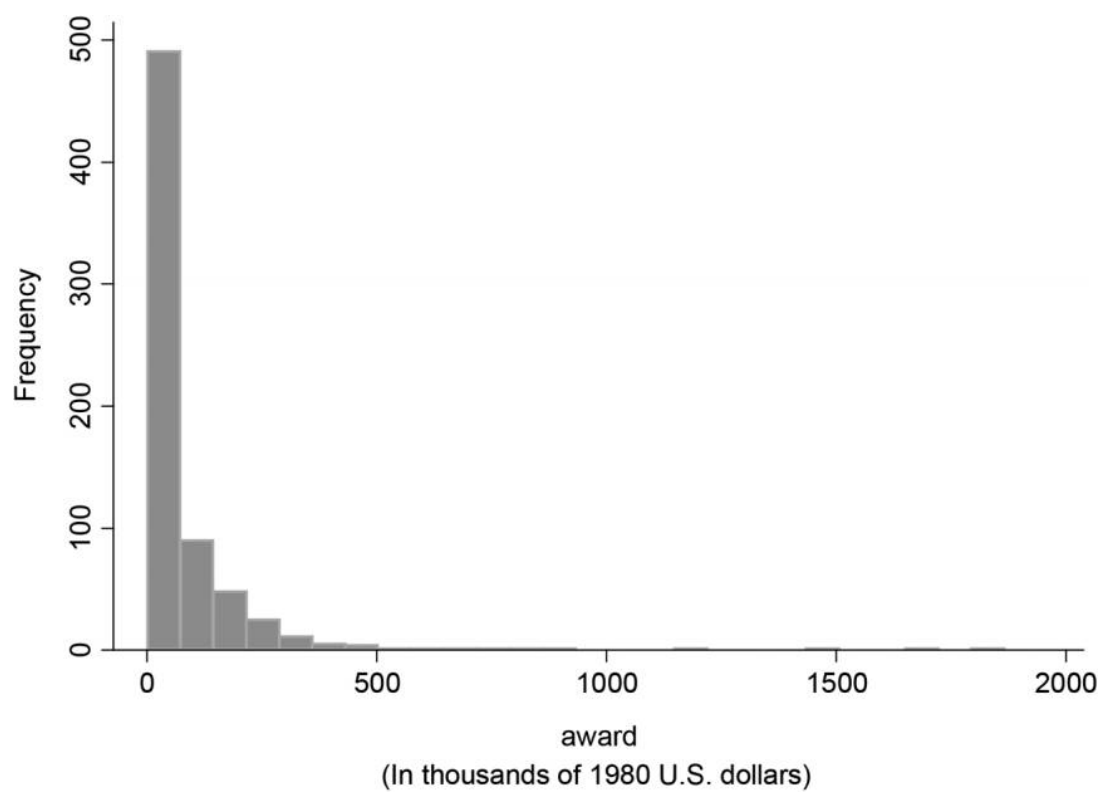

Figure 2. Histogram of Salvage Awards

District Court for the Southern District of New York (ninety-five cases or 13.9 percent), the District Court for the Eastern District of New York (eighty-one cases or 11.8 percent), the District Court for the Southern District of Florida (fifty-three cases or 7.8 percent), the District Court for the District of Massachusetts (forty cases or 5.9 percent), and the District Court for the Eastern District of Virginia (twenty-seven cases or 4.0 percent).

Finally, Figure 2 plots the histogram of the salvage awards. The awards are bounded below by zero and skewed to the right: 72.2 percent of the awards are less than $\$ 74,000$ (the mean award), and 98.5 percent are less than $\$ 500,000$. Accordingly, the dependent variable in the empirical analysis in Part IV is the natural logarithm of the award. Figure 3 plots the histogram of the log-transformed salvage awards, overlaid with an appropriately scaled normal density. ${ }^{110}$ It suggests that the lognormal distribution is a reasonable modeling assumption.

\section{V E M P I R I C A L A N A L Y I S}

The empirical analysis aims to make inferences about the mapping from Blackwall factors to salvage awards implicit in the salvage

110 The overlaid normal density is appropriately scaled in that it has the same mean and standard deviation as the data. 


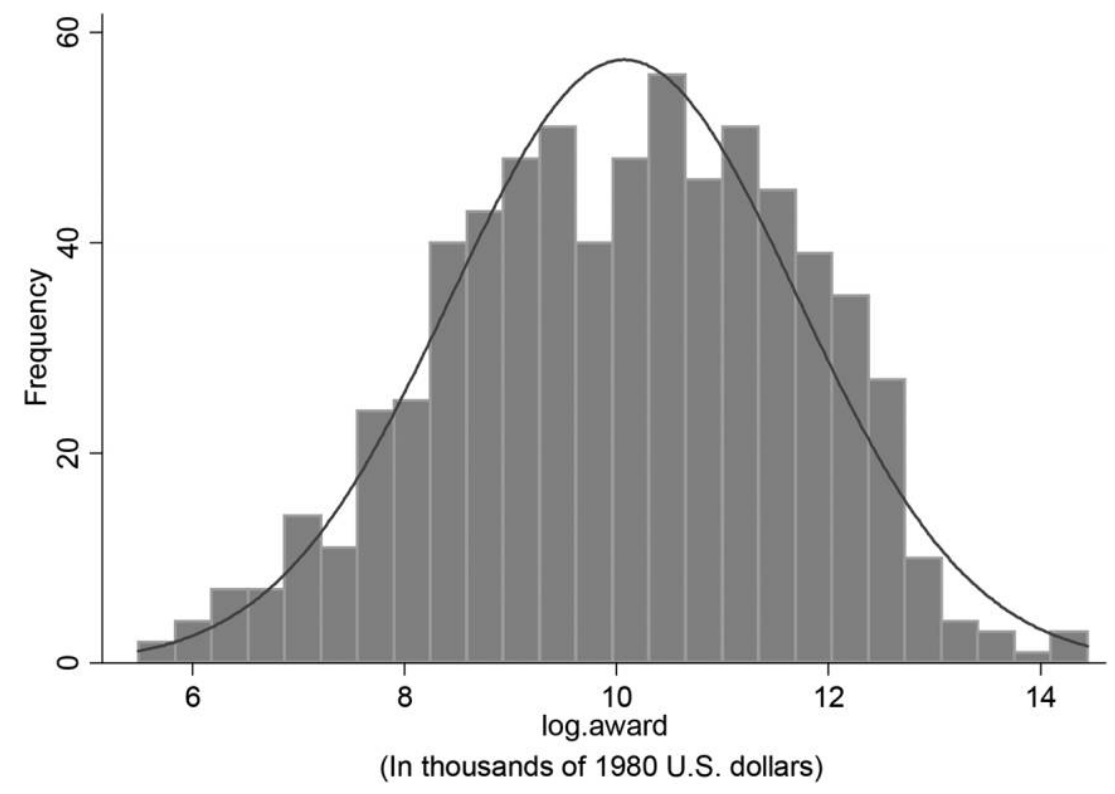

Figure 3. Histogram of Log Awards

cases. Two statistical methods are employed: (i) fractional polynomial regression, which assumes the mapping is a smooth function and uses a fractional polynomial to approximate the function, and (ii) regression tree analysis, which assumes a hierarchical and dichotomous decision process and represents the mapping as a binary decision tree.

\section{A. Fractional Polynomial Regression Analysis}

1. Methodology. One way to model how courts map their findings on the Blackwall factors into salvage awards is with a function-that is, a correspondence that associates a salvage award with every possible combination of Blackwall factors. ${ }^{111}$ Formally, let $X=$ $\{0,1\}^{5} \times \mathbb{R}_{+}$denote the set of all possible combinations of the Blackwall factors and $Y=\mathbb{R}_{+}$denote the set of all possible salvage awards. It is assumed that there exists a function, $f: X \rightarrow Y$, which maps each factor combination $x \in X$ to an award $y \in Y$. It is also assumed that $f$ is smooth (that is, infinitely differentiable).

${ }^{111}$ Modeling judicial decisions and legal rules as functions that map facts to outcomes is a common approach in political science and empirical legal studies. 
Fractional polynomial regression is a parametric approach to estimating the unknown function $f .{ }^{112}$ A fractional polynomial is an extension of a conventional polynomial that allows for noninteger and negative powers. In reliance on the Stone-Weierstrass approximation theorem, ${ }^{113}$ conventional polynomials are often used to approximate unknown smooth functions. However, conventional polynomial regression generally involves a trade-off between flexibility (that is, fit) and parsimony. Fractional polynomial regression provides a flexible yet parsimonious parametric method for approximating unknown smooth functions.

The standard multivariable fractional polynomial (MFP) regression model may be expressed as

$$
y_{t}=f\left(x_{t} ; \theta\right)=b_{0}+\sum_{i=1}^{h} b_{i} x_{i t}+\sum_{i=h+1}^{n} \sum_{j=1}^{m} b_{i j} x_{i t}^{\left(p_{j}\right)}+\varepsilon_{t}, \quad t=1, \ldots, T,
$$

where $\theta=\left(b_{0}, b_{1}, \ldots, b_{h}, b_{h+1,1}, \ldots, b_{h+1, m}, \ldots, b_{n 1}, \ldots, b_{n m}, \sigma^{2}\right)$ is the vector of parameters to be estimated, $\varepsilon_{t} \sim N\left(0, \sigma^{2}\right)$ is the independent and identically distributed error term, and the round bracket notation signifies the Box-Tidwell transformation,

$$
X_{i t}^{\left(p_{i}\right)}=\left\{\begin{array}{c}
x_{i t}^{\left(p_{j}\right)} \text { for } p_{j} \neq 0 \\
\ln x_{i t} \text { for } p_{j}=0
\end{array}\right.
$$

The MFP algorithm selects both the covariates, $x_{1}, \ldots, x_{h}, x_{h+1}, \ldots, x_{n^{\prime}}$ and the powers, $p_{1}, \ldots, p_{m}$, for the continuous covariates. (The first $h$ covariates, $x_{1}, \ldots, x_{h^{\prime}}$ are categorical, and the remaining covariates, $X_{h+1}, \ldots, X_{n^{\prime}}$ are continuous.) The researcher predefines the set of potential covariates; the set of potential powers, denoted $P$; and the maximum degree of the fractional polynomial, denoted $M$. The researcher also predefines two significance levels: $\alpha_{1}$, which determines the critical value for covariate selection, and $\alpha_{2}$, which determines the critical value for power selection. The covariates are selected using a backward elimination procedure in which the potential covariates are iteratively removed and added based on a sequence of signifi-

\footnotetext{
${ }^{112}$ See generally Patrick Royston and Willi Sauerbrei, Multivariable Model-Building: A Pragmatic Approach to Regression Analysis Based on Fractional Polynomials for Modelling Continuous Variables (Wiley 2008).

${ }^{113}$ The Stone-Weierstrass approximation theorem states (or, more precisely, implies) that any continuous, real-valued function on a compact subspace of $\mathbb{R}^{n}$ can be uniformly approximated by polynomials. See, for example, Robert S. Strichartz, The Way of Analysis 399 (Jones \& Bartlett rev ed 2000).
} 
cance tests at level $\alpha_{1}{ }^{114}$ The powers are selected using a closed test procedure in which an $M$-degree fractional polynomial is tested at level $\alpha_{2}$ against a linear model and then, if and as necessary, against increasingly complex fractional polynomials. ${ }^{15}$ Once the covariates and powers are selected, the parameter vector $\theta$ is estimated via maximum likelihood.

2. Results. In the benchmark MFP regression model, labeled Model 1 , the dependent variable is the log-transformed salvage award and the set of covariates comprises the six Blackwall factors. In addition, the set of potential powers is $P=\{-2,-1,0.5,0,0.5,1,2, \ldots, 5\}$, and the maximum degree of the fractional polynomial is $M=5 .{ }^{116}$ Finally, the significance level for covariate selection is $\alpha_{1}=1$ and the significance level for power selection is $\alpha_{2}=0.05$. Note that setting $\alpha_{1}=1$ forces the MFP algorithm to select all the covariates into the model, which is theoretically justified here by the doctrinal principle that courts must apply all of the Blackwall factors in determining salvage awards. ${ }^{117}$

Table 6 presents the maximum likelihood estimates for Model 1. It also reports the "visiting order" of the covariates under the MFP algorithm, which signifies the ranking of the covariates in terms of significance. ${ }^{118}$ There are four main takeaways from Table 6. First, although the model allows for a fifth-degree fractional polynomial in factor5 (the one continuous covariate) with powers ranging from -2 to 5, the MFP algorithm selects a simple log transformation (that is, a one-degree fractional polynomial with power zero). This suggests a power law relationship between the award and the value of the property saved; more specifically, $y=a x^{0.6}$, where $y$ is the award, $x$ is the value of the property saved, and the scale parameter $a$ depends on the five binary Blackwall factors. (Figure 4 illustrates the power law relationship for the modal case, in which every binary factor is low. Figure 5 illustrates that the power law relationship between

${ }^{114}$ See generally Royston and Sauerbrei, Multivariable Model-Building at chs 2, 6 (cited in note 112).

${ }^{115}$ See generally id at chs 4, 6. See also Willi Sauerbrei and Patrick Royston, Building Multivariable Prognostic and Diagnostic Models: Transformation of the Predictors Using Fractional Polynomials, 162 J Royal Statistical Society, Series A 71 (1999); Willi Sauerbrei and Patrick Royston, Corrigendum: Building Multivariable Prognostic and Diagnostic Models: Transformation of the Predictors Using Fractional Polynomials, 165 J Royal Statistical Society, Series A 399 (2002).

116 This proves never to be a binding constraint.

${ }_{117}$ See Part II.B.3.

${ }^{118}$ The visiting order of the covariates is determined according to the p-value for omitting each covariate from the model. See Royston and Sauerbrei, Multivariable Model-Building at 118 (cited in note 112). 
Table 6. Model 1 - Benchmark MFP Regression

\begin{tabular}{|c|c|c|c|c|c|}
\hline \multicolumn{2}{|l|}{ Variable } & \multicolumn{2}{|c|}{ Coefficient } & \multirow{2}{*}{$\begin{array}{c}\begin{array}{c}\text { Standard } \\
\text { Error }\end{array} \\
0.073\end{array}$} & \multirow{2}{*}{$\begin{array}{c}\text { Visiting } \\
\text { Order }\end{array}$} \\
\hline factor1 & Labor expended by salvors & 0.890 & $\star \star \star$ & & \\
\hline factor2 & Skill displayed by salvors & 0.135 & * & 0.071 & 6 \\
\hline factor3 & Danger to salvors' property & 0.211 & $\star \star \star$ & 0.077 & 5 \\
\hline factor4 & Risk incurred by salvors & 0.257 & $\star \star \star$ & 0.092 & 4 \\
\hline log.factor5 & Value of property saved & 0.581 & $\star \star \star$ & 0.018 & 1 \\
\hline factor6 & Danger to property saved & 0.683 & $\star \star \star$ & 0.073 & 3 \\
\hline Constant & & 1.804 & $\star \star \star$ & 0.216 & \\
\hline \multicolumn{2}{|c|}{ Loglikelihood } & -898.900 & & & \\
\hline \multicolumn{2}{|l|}{ OLS R ${ }^{2}$} & 0.697 & & & \\
\hline \multicolumn{2}{|c|}{ Observations } & 684 & & & \\
\hline
\end{tabular}

Notes: Dependent variable: log.award. Maximum likelihood estimates. White robust standard errors.

$\star \star \star$ Significant at 1 percent level.

* Significant at 10 percent level.

the award and the value of the property saved implies the L-shaped relationship displayed in Figure 1 between the award percentage and the value of the property saved.) Second, the estimates suggest that each factor is positively related to the salvage award, as well as statistically significant. Third, the visiting order suggests the following ranking of the factors (in descending order): the value of the property saved (factor 5); the labor expended by the salvors (factor 1); the danger to the property saved (factor 6); the risk incurred by the salvors (factor 4); the danger to salvors' property (factor 3); and the skill displayed by the salvors (factor 2). Fourth, the estimates suggest that the model, which includes as covariates only the Blackwall factors, explains slightly more than two-thirds of the variation in the salvage awards. Indeed, re-estimating the model with restricted sets of covariates further reveals that (i) the value of the property saved (factor 5) alone explains half of the variation in the awards and (ii) the top three factors $(5,1$, and 6) account for nearly all of the collective explanatory power of all six factors.

To check the sensitivity of the benchmark results to the significance level for power selection, the set of potential powers, and the set of covariates, four additional models are estimated. In 


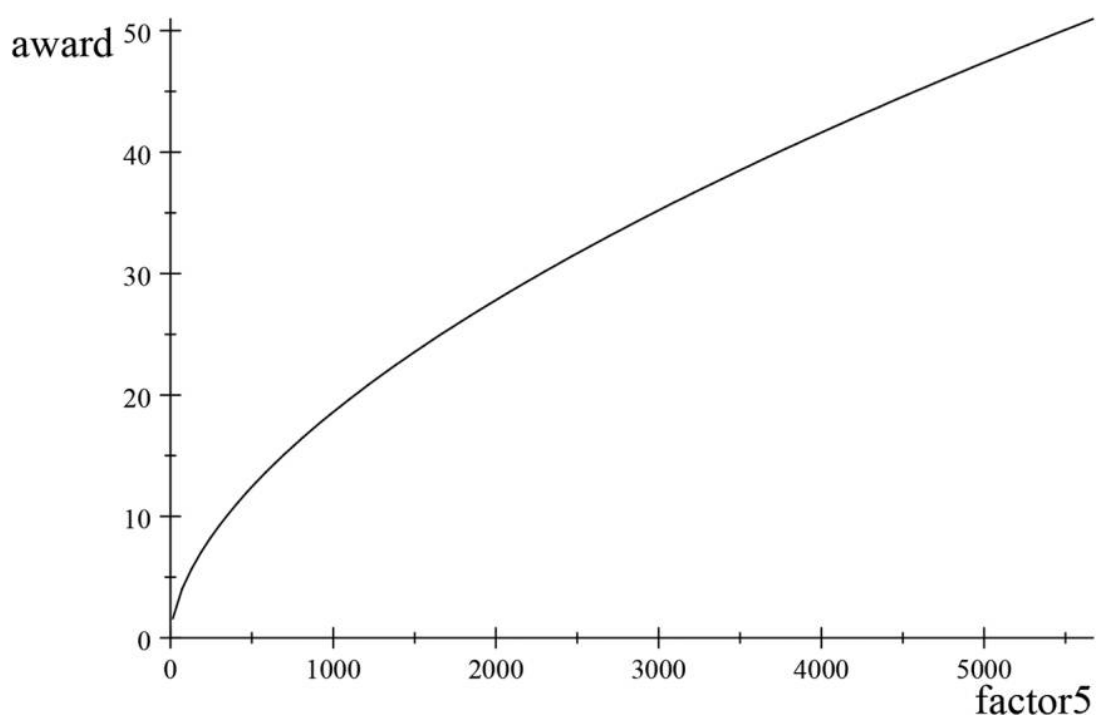

Figure 4. Power Law Relationship (award and factor5 in thousands)

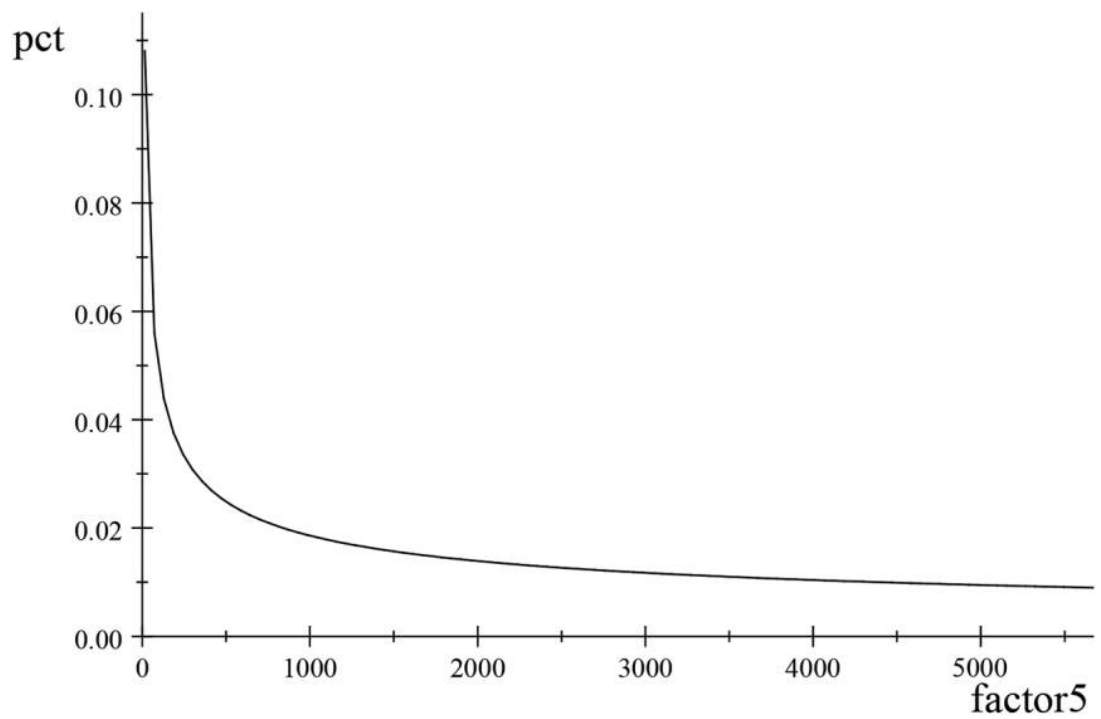

Figure 5. L-Shaped Relationship (factor5 in thousands) 
Models 2 and 3, the significance level for power selection is changed to $\alpha_{2}=0.01$ and $\alpha_{2}=0.10$, respectively. In Model 4, the set of potential powers is expanded to $P=\{-4,-3,-2,-1,-0.5,0,0.5,1,2, \ldots, 8\}$. In Model 5, the set of covariates is expanded to include the following controls: an indicator for whether the award was determined with reference to a moiety or other fixed percentage; circuit fixed effects (indicators for the federal judicial circuit of the court); and era fixed effects (indicators for whether the case pre-dates The Blackwall or post-dates 1992).

The results for Models 2, 3, and 4 are identical to the benchmark results, suggesting that the MFP regression results are robust to the choice of significance level for power selection and the set of potential powers. Table 7 presents the results for Model 5. It shows that the main takeaways from the benchmark results remain unchanged after including the additional controls, with one exception: the ranking

Table 7. Model 5

\begin{tabular}{|c|c|c|c|c|c|}
\hline \multicolumn{2}{|l|}{ Variable } & \multicolumn{2}{|c|}{ Coefficient } & \multirow{2}{*}{$\begin{array}{c}\text { Standard } \\
\text { Error }\end{array}$} & \multirow{2}{*}{$\begin{array}{c}\text { Visiting } \\
\text { Order } \\
2\end{array}$} \\
\hline factor1 & Labor expended by salvors & 0.791 & 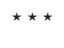 & & \\
\hline factor2 & Skill displayed by salvors & 0.183 & $\star \star$ & 0.073 & 5 \\
\hline factor3 & Danger to salvors' property & 0.231 & $\star \star \star$ & 0.076 & 4 \\
\hline factor4 & Risk incurred by salvors & 0.191 & $\star \star$ & 0.087 & 6 \\
\hline $\log$ factor 5 & Value of property saved & 0.593 & $\star \star \star$ & 0.018 & 1 \\
\hline factor6 & Danger to property saved & 0.642 & $\star \star \star$ & 0.069 & 3 \\
\hline Constant & & 1.507 & $\star \star \star$ & 0.232 & \\
\hline \multicolumn{2}{|c|}{ Moiety indicator } & Yes & & & \\
\hline \multicolumn{2}{|c|}{ Circuit fixed effects } & Yes & & & \\
\hline \multicolumn{2}{|c|}{ Era fixed effect } & Yes & & & \\
\hline \multicolumn{2}{|c|}{ Loglikelihood } & -864.051 & & & \\
\hline \multicolumn{2}{|l|}{ OLS $\mathrm{R}^{2}$} & 0.701 & & & \\
\hline \multicolumn{2}{|c|}{ Observations } & 684 & & & \\
\hline
\end{tabular}

Notes: Dependent variable: log.award. Maximum likelihood estimates. White robust standard errors.

$\star \star \star$ Significant at 1 percent level.

$\star \star$ Significant at 5 percent level. 
of the bottom three factors. Specifically, in Model 5, the bottom three factors (in descending order) are the danger to the salvors' property (factor 3), the skill displayed by the salvors (factor 2), and the risk incurred by the salvors (factor 4).

As a further robustness check, Models 1 and 5 are re-estimated with standard errors clustered by circuit and year. ${ }^{119}$ This allows the error terms (unobserved heterogeneity) to be correlated within circuits across time and across circuits in a given year. Once again, the main takeaways remain unchanged, with one exception: the coefficient for factor4 (risk to salvors) is no longer statistically significant at common levels. This result is likely due to insufficient independent variation at the circuit level, which in turn is likely due to the relatively small number of cases in which the risk incurred by the salvors was high (125 cases) and the relatively large correlation (0.44) between factor4 and factor3 (danger to salvors' property). Indeed, no other (binary) factor was adjudged to be high in so few cases (the next lowest, factor3, was high in 186 cases), and no other pair of factors are so highly correlated (the next highest pairwise correlation among the factors is 0.29 ). When both models are re-estimated again with standard errors clustered by circuit and year but with an alternative variable, factor 314 , in place of factor3 and factor4, which indicates whether factor3 or factor 4 was high, the coefficient on factor3|4 is statistically significant in both models.

\section{B. Regression Tree Analysis}

1. Methodology. An alternative way to model how courts map their findings on the Blackwall factors into salvage awards is with a binary decision tree. Regression tree analysis is a nonparametric approach to estimating the tree that best fits the data. Regression tree analysis falls under the umbrella of so-called classification and regression tree analysis (CART) ${ }^{120}$ When the outcome variable is

${ }^{119}$ In order to two-way cluster by circuit and year, the estimation uses recently developed multiway clustering methods. See A. Colin Cameron, Jonah B. Gelbach, and Douglas L. Miller, Robust Inference with Multiway Clustering, 29 J Bus \& Econ Statistics 238 (2011); Samuel B. Thompson, Simple Formulas for Standard Errors That Cluster by Both Firm and Time, 99 J Financial Econ 1 (2011). In addition, on account of the small number of federal judicial circuits, the estimation also uses the socalled wild cluster bootstrap-t procedure. See A. Colin Cameron, Jonah B. Gelbach, and Douglas L. Miller, Bootstrap-based Improvements for Inference with Clustered Errors, 90 Rev Econ \& Statistics 414 (2008).

120 See generally Breiman, et al, Classification and Regression Trees (cited in note 24). See also Brian D. Ripley, Pattern Recognition and Neural Networks ch 7 (Cambridge 1996); Clifton D. Sutton, Classification and Regression Trees, Bagging, 
continuous, CART is referred to as regression tree analysis. When the outcome variable is categorical, CART is referred to as classification tree analysis. ${ }^{121}$

The CART algorithm grows the tree by recursively partitioning the data according to the predictor variables, $x_{1}, \ldots, x_{n}$, to minimize the heterogeneity ("impurity") of the outcome variable $y$ in each partition ("node"), subject to four criteria/limitations predefined by the researcher. The first is the measure of impurity. In the case of regression tree analysis, the standard measure is least squares deviation (LSD), which measures within-node variance. Formally, the LSD impurity measure is given by

$$
\frac{1}{N(\tau)} \sum_{t \in \tau}\left[y_{t}-\bar{y}(\tau)\right]^{2}
$$

where $N(\tau)$ is the number of cases in node $\tau, y_{t}$ is the outcome in case $t$, and $\bar{y}(\tau)$ is the mean outcome among the cases in node $\tau$. The other three criteria or limitations are the minimum improvement in the impurity measure required for a split, the maximum tree depth (levels beneath the root node), and the minimum node size (cases per node). After the tree is grown, it typically is pruned to avoid overfitting. The standard pruning procedure selects the smallest subtree within one standard error of the minimum cost subtree (the subtree with the lowest mean squared error), where cost typically is estimated via tenfold cross-validation.

The following is a sketch of the steps performed by the CART algorithm in constructing the final tree. ${ }^{122}$ First, starting with the root node, CART performs all possible splits on each of the predictors and calculates the impurity improvement achieved by each split. Second, it selects the split that achieves the maximum impurity improvement and partitions the data into left and right child nodes. Third, it repeats the first two steps for each of the nonterminal nodes and grows the largest possible tree (subject to the minimum impurity improvement criterion and the maximum tree depth and minimum node size limitations). Once the tree is grown, the mean outcome of the cases in each terminal node becomes the pre-

and Boosting, in C.R. Rao, E.L. Wegman, and J.L. Solka, eds, Data Mining and Data Visualization 330 (Elsevier 2005).

${ }^{121}$ As stated in note 36, a small handful of studies in the legal literature use classification trees to conduct empirical doctrinal analysis

${ }^{122}$ See Yisehac Yohannes and Patrick Webb, Classification and Regression Trees, CART: A User Manual for Identifying Indicators of Vulnerability to Famine and Chronic Food Insecurity 27 (IFPRI 1999). 
dicted value of the outcome variable for cases in that terminal node. Finally, CART applies its pruning procedure: it first calculates the cost (mean squared error) of each subtree and then selects the smallest subtree that is within one standard error of the minimum cost subtree.

2. Results. In the benchmark regression tree model, labeled Model 6 , the outcome variable is the log-transformed salvage award and the set of predictors comprises the six Blackwall factors (where the value of the property saved (factor 5) is log-transformed). In addition, the impurity measure is LSD, the minimum impurity improvement required to split a node is 0.0001 , the maximum tree depth is ten, ${ }^{123}$ and the minimum node size is thirty-five cases ( 5 percent). After the initial tree is grown (subject to the foregoing criteria or limitations), it is pruned to avoid overfitting according to the standard pruning procedure described above.

Figure 6 displays the benchmark regression tree and associated statistics. ${ }^{124}$ Figure 7 displays the relative importance of the six

${ }^{123}$ This proves never to be a binding constraint.

${ }^{124}$ The way to read the tree is as follows. Starting at the top with the root node, cases with "low" awards, in which log.award $\leq 12.165$ (that is, the award is less than or equal to $\$ 191,952)$, proceed down the left branch. Cases with "high" awards, in which the award is greater than $\$ 191,952$, proceed down the right branch. Each subbranch gives a rule for further splits. Nodes without subbranches beneath them are terminal nodes, and the mean award in a terminal node is the predicted award for all cases therein. Moving down the left branch of the tree, cases with low awards are further split based on the value of the property saved (factor 5). For cases in which $\log$.factor $5 \leq 10.140$ (that is, the value of the property saved is less than or equal to $\$ 25,336$ ), the predicted value of log.award is 7.669 (that is, the predicted award is $\$ 2,141)$. However, cases in which the value of the property saved is greater than $\$ 25,336$ are further split based on factor1 (the labor expended by the salvors). For cases in which factor $1=0$ (that is, the labor expended by the salvors is low), the predicted award is $\$ 6,522$. For cases in which the labor expended is high, the predicted award is $\$ 17,171$. Moving down the right branch of tree, cases with high awards are further split based on the labor expended by the salvors (factor 1) and then on the value of the property saved (factor 5). For cases in which the labor expended is low and the value of the property saved is greater than $\$ 984,609$, the predicted award is $\$ 49,563$. For cases in which the labor expended is high and the value of the property saved is greater than $\$ 1,293,678$, the predicted award is $\$ 171,957$. Other cases are further split based on the danger to the property saved (factor 6). For cases in which the labor expended is low and the value of the property saved is less than or equal to $\$ 984,609$, the predicted award is $\$ 10,107$ for cases in which the danger to the property saved is low and $\$ 28,624$ for cases in which the danger is high. For cases in which the labor expended is high and the value of the property saved is less than or equal to $\$ 1,293,678$, the predicted award is $\$ 37,987$ for cases in which the danger to the property saved is low and $\$ 90,219$ for cases in which the danger is high. 


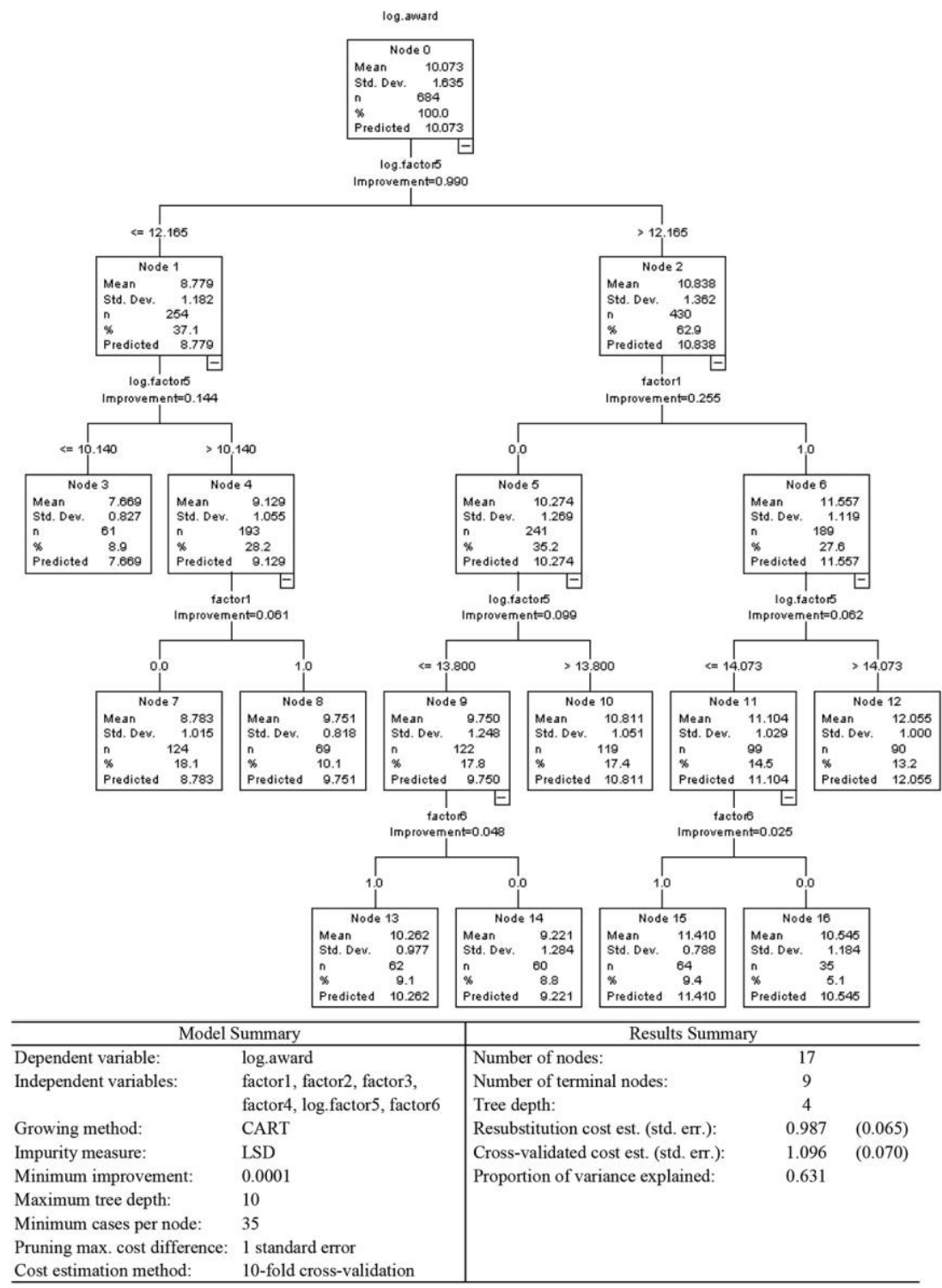

Figure 6. Model 6-Benchmark Regression Tree 


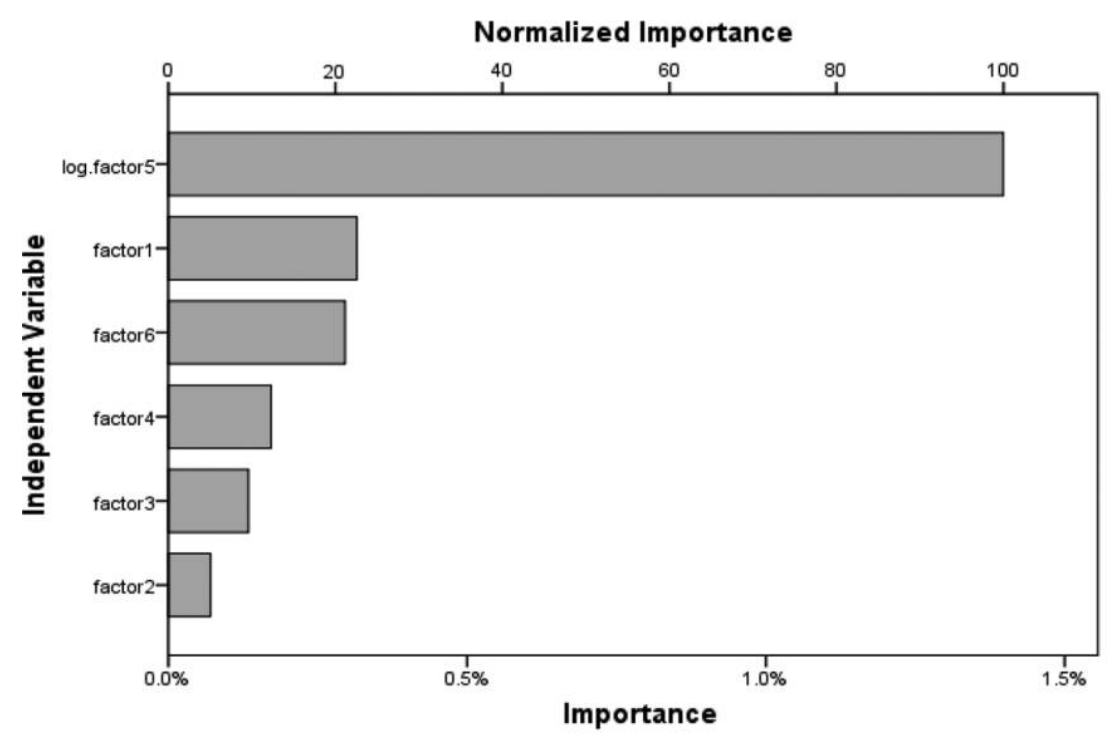

Growing Method:CRT

Dependent Variable:log. award

\begin{tabular}{lcc}
\hline Factor & Importance & Normalized Importance \\
\hline log.factor 5 & 1.397 & 100.0 \\
factor 1 & 0.316 & 22.6 \\
factor6 & 0.296 & 21.2 \\
factor4 & 0.172 & 12.3 \\
factor3 & 0.134 & 9.6 \\
factor 2 & 0.071 & 5.1 \\
\hline
\end{tabular}

Figure 7. Importance of Factors

Blackwall factors to the model. ${ }^{125}$ There are three main takeaways from these Figures. First, the tree is fairly simple-it classifies cases into nine terminal nodes using three factors (listed in descending order of importance): the value of the property saved (factor 5); the

125 To calculate the importance score of a variable, CART sums over all nodes the impurity improvements attributable to the variable in its role as primary or surrogate splitter. A variable is the primary splitter at a node if the maximum impurity improvement is achieved by splitting on that variable. It is a surrogate splitter if splitting on that variable achieves at least the minimum impurity improvement required for a split. 
labor expended by the salvors (factor 1); and the danger to the property saved (factor 6). Note that this does not imply that the other factors are not important. They are; they account in part for the variation of awards within the terminal nodes. ${ }^{126}$ Second, the complete ranking of factors is the same as in the benchmark MFP regression model: after the top three, the bottom three are (in descending order of importance): the risk incurred by the salvors (factor 4); the danger to the salvors' property (factor 3); and the skill displayed by the salvors (factor 2). Third, the model, which includes as predictors only the six Blackwall factors, explains slightly less than two-thirds of the variation in the salvage awards. As before, regrowing the tree with restricted sets of predictors reveals that (i) the value of the property saved (factor 5) alone explains half of the variation in the awards and (ii) the top three factors (factors 5, 1, and 6) account for nearly all of the collective explanatory power of all six factors.

To check the sensitivity of the benchmark results to the minimum node size and the set of predictors, two additional trees are grown. In Model 7, the minimum node size is reduced to ten cases (1.5 percent). In Model 8, the set of predictors is expanded to include the moiety indicator and circuit and era indicators. In the case of Model 7, the tree is more complex than the benchmark tree (it classifies cases into seventeen terminal nodes); however, it still uses only factors 5,1 , and 6 to classify cases and the other main takeaways are also unchanged. Indeed, reducing the minimum node size to ten cases increases the proportion of variance explained to slightly more than two-thirds (however, the cross-validated cost estimate also increases slightly, due to the increased complexity of the tree). In the case of Model 8, the tree is virtually identical to the benchmark tree, and the main takeaways remain unchanged. The only difference in the results is a slightly higher cross-validated cost estimate, due to the additional predictors. Unlike in the MFP regression analysis, however, the inclusion of the additional predictors does not alter the ranking of the factors.

\section{C O N C L US I O N}

Under U.S. maritime law, a salvor of imperiled maritime property on navigable waters is entitled to a monetary award from the owner. When the salvage service is rendered voluntarily in the absence of a contract, the court must determine the salvage award according to the six factors enumerated by the Supreme Court in The Blackwall: (1) the labor expended by the salvors, (2) the skill displayed by the salvors, (3) the danger to the salvors' property, (4) the risk incurred

${ }^{126}$ In addition, each qualifies as a surrogate splitter at multiple nodes. 
by the salvors, $(5)$ the value of the property saved, and (6) the danger to the property saved. The law, however, does not specify a precise formula or rule for calculating awards on the basis of the Blackwall factors; it provides only a handful of general principles to guide courts and delimit their discretion.

This Article investigates empirically how courts turn their findings on the Blackwall factors into salvage awards. It employs two statistical methods-fractional polynomial regression and regression tree analysis - to make inferences about the mapping from factors to awards implicit in the reported decisions by U.S. courts in salvage cases from 1799 to 2007 . Three main conclusions emerge from the empirical analysis. First, the results evidence a positive, statistically significant relationship between the Blackwall factors and the magnitude of the salvage award, and they indicate a power law relationship between the award and the value of the property saved. Second, the results suggest a ranking of the Blackwall factors, in which the three most important factors, in descending order of importance, are the value of the property saved (factor 5), the labor expended by the salvors (factor 1), and the danger to the property saved (factor 6). Third, the Blackwall factors collectively explain approximately two-thirds of the variation in the salvage awards.

An important contribution of this Article is that it represents the first empirical doctrinal study of the law governing U.S. marine salvage awards. As such, it complements the traditional doctrinal analysis offered by other maritime commentators. Another important contribution of the Article is that it showcases and juxtaposes fractional polynomial regression and regression tree analysis, two very different yet complementary statistical methods that are well suited to empirical doctrinal analysis but are underutilized in legal scholarship.

\section{A P P E N D I X}

1. Falliage $v$ The Hope, 8 F Cas 975 (Adm Pa 1779) (No 4,626).

2. Weeks $v$ The Catharina Maria, 29 F Cas 579 (D Pa 1790) (No 17,351).

3. Warder v La Belle Creole, 29 F Cas 215 (D Pa 1792) (No 17,165).

4. Hindry $v$ The Priscilla, 12 F Cas 201 (D SC 1792) (No 6,515).

5. The Mary Ford, 3 US (3 Dall) 188 (1796).

6. Wilkie $v$ Two Hundred Five Boxes of Sugar, 29 F Cas 1247 (D SC 1796) (No 17,662).

7. Concklin $v$ The Harmony, 6 F Cas 259 (D NY 1797) (No 3,089). 
8. Booth $v$ L'Esperanza, 3 F Cas 885 (D SC 1798) (No 1,647).

9. Schutz $v$ The Nancy, 21 F Cas 759 (D SC 1799) (No 12,493).

10. Cowell $v$ The Brothers, 6 F Cas 668 (D SC 1799) (No 3,294).

11. Clayton $v$ The Harmony, 5 F Cas 994 (D Pa 1799) (No 2,871).

12. Cross $v$ The Dolphin, 6 F Cas 892 (D SC 1800) (No 3,432).

13. Brevoor $v$ The Fair American, 4 F Cas 71 (D Pa 1800) (No 1,847).

14. Stephens $v$ Bales of Cotton, 22 F Cas 1278 (D SC 1800) (No 13,366).

15. Kennedy $v$ Ricker, 14 F Cas 318 (D NH 1801) (No 7,705).

16. Talbot $v$ Seeman, 5 US (1 Cranch) 1 (1801).

17. Taylor $v$ Twenty-Five Thousand Dollars, 23 F Cas 806 (D SC 1801) (No 13,807).

18. British Consul v Twenty-Two Pipes, 4 F Cas 173 (D SC 1801) (No 1,900).

19. Cross $v$ The Bellona, 6 F Cas 886 (D SC 1803) (No 3,428).

20. Morehouse $v$ The Jefferson, 17 F Cas 738 (DNY 1803) (No 9,793).

21. Bass $v$ Five Negroes, 2 F Cas 1006 (D SC 1803) (No 1,093).

22. Mason $v$ The Blaireau, 6 US (2 Cranch) 240 (1804).

23. Jerby $v$ One Hundred e) Ninety-Four Slaves, 13 F Cas 550 (D SC 1806) (No 7,288).

24. Taylor $v$ The Cato, 23 F Cas 752 (D Pa 1806) (No 13,786).

25. Bond $v$ The Cora, 3 F Cas 835 (D Pa 1806) (No 1,620).

26. Small $v$ The Messenger, 22 F Cas 366 (D Pa 1807) (No 12,961).

27. Bell $v$ The Ann, 3 F Cas 88 (D Pa 1807) (No 1,245).

28. Flinn $v$ The Leander, 9 F Cas 275 (D SC 1808) (No 4,870).

29. Tyson $v$ Prior, 24 F Cas 489 (CC D Mass 1812) (No 14,319).

30. Rowe $v$ The Brig, $20 \mathrm{~F}$ Cas 1281 (CC D Mass 1818) (No 12,093).

31. The Sybil, 17 US 98 (1819), affg, 9 F Cas 141 (CC D SC 1816) (No 4,824).

32. The Maria Josepha, 16 F Cas 733 (CC D SC 1819) (No 9,078).

33. Hollingsworth $v$ Seventy Doubloons, 12 F Cas 380 (ED Pa 1820) (No 6,620).

34. Le Tigre, 15 F Cas 404 (D NJ 1820) (No 8,281).

35. The Two Catherines, 24 F Cas 424 (D RI 1821) (No 14,288).

36. Lewis $V$ The Elizabeth $\oplus$ ) Jane, 8 F Cas 474 (D Me 1823) (No 4,356).

37. Am Ins Co v Johnson, 1 F Cas 665 (SDNY 1827) (No 303).

38. Peabody $v$ Proceeds of Twenty-Eight Bags of Cotton, 19 F Cas 39 (D Mass 1829) (No 10,869).

39. Hand $v$ The Elvira, $11 \mathrm{~F}$ Cas 413 (ED Pa 1829) (No 6,015).

40. The Waterloo, 29 F Cas 399 (SDNY 1830) (No 17,257). 
41. The Galaxy, 9 F Cas 1075 (SDNY 1831) (No 5,186).

42. Parter $v$ The Friendship, 18 F Cas 1271 (D Mass 1831) (No 10,783).

43. The Emulous, 8 F Cas 704 (CC D Mass 1832) (No 4,480).

44. The Boston, 3 F Cas 932 (CC D Mass 1833) (No 1,673).

45. The Henry Ewbank, 11 F Cas 1166 (CC D Mass 1833) (No 6,376).

46. The Lexington, 15 F Cas 501 (D Fla 1835) (No 8,336).

47. Courcier v Ritter, 6 F Cas 644 (SD Fla 1836) (No 3,282).

48. The Bee, 3 F Cas 41 (D Me 1836) (No 1,219).

49. The Dorothea Foster, 1 F Cas 989 (D Fla 1836) (No 429).

50. The America, 1 F Cas 596 (SD Fla 1836) (No 279).

51. Lea $v$ The Alexander, 15 F Cas 91 (CC D SC 1836) (No 12,630).

52. The Rising Sun, 20 F Cas 828 (D Me 1837) (No 11,858).

53. The Ella Hand, 8 F Cas 502 (SD Fla 1837) (No 4,396).

54. Williams $v$ The Adolphe, 29 F Cas 1350 (D RI 1837) (No 17,712).

55. The La Bruce, 14 F Cas 905 (D Fla 1837) (No 7,963).

56. The Howard, 12 F Cas 630 (SD Fla 1838) (No 6,752a).

57. Smith $v$ The Joseph Stewart, 22 F Cas 582 (ED Pa 1838) (No 13,070).

58. The Alabamian, $1 \mathrm{~F}$ Cas 283 (SD Fla 1839) (No 128).

59. The Amethyst, 1 F Cas 762 (D Me 1840) (No 330).

60. The Herman, 12 F Cas 23 (SD Fla 1840) (No 6,406).

61. Walter $v$ The Montgomery, 29 F Cas 113 (D Fla 1840) (No 17,120).

62. The Emblem, 8 F Cas 611 (D Me 1840) (No 4,434).

63. Bearse $v$ Three Hundred $\uplus$ Forty Pigs of Copper, 2 F Cas 1192 (CC D Mass 1840) (No 1,193).

64. The Amistad, 40 US (15 Pet) 518 (1841).

65. Bean $v$ The Grace Brown, 2 F Cas 1136 (ED Va 1841) (No 1,171).

66. Hartshorn $v$ Twenty-Five Cases Silk, 11 F Cas 713 (SDNY 1841) (No 6,168a).

67. Lears $v$ One Cask Oil, 15 F Cas 105 (SDNY 1842) (No 8,161a).

68. Sprague $v$ One Hundred $\oplus$ Forty Barrels of Flour, 22 F Cas 968 (CC D Mass 1842) (No 13,253).

69. Evans $v$ The Charles, 8 F Cas 838 (D La 1842) (No 4,556).

70. Cartwell $v$ The John Taylor, 5 F Cas 228 (ED La 1842) (No 2,482).

71. The North America, 18 F Cas 333 (SD Fla 1843) (No 10,313). 
72. Sanderson v The Ann Johnson, 21 F Cas 327 (SD Fla 1843) (No 12,297a).

73. Johnson v Certain Goods, 13 F Cas 736 (D Mass 1843) (No 7,377).

74. Two Hundred e) Ten Barrels of Oil, 24 F Cas 448 (D Mass 1844) (No 14,297).

75. Howland $v$ Two Hundred e Ten Barrels of Oil, 12 F Cas 745 (D Mass 1844) (No 6,801).

76. The John Gilpin, 13 F Cas 675 (SDNY 1845) (No 7,345).

77. The Tellumah, 23 F Cas 835 (SD Fla 1846) (No 13,823).

78. The York, 30 F Cas 818 (SD Fla 1846) (No 18,140).

79. The John Wurts, 13 F Cas 903 (SDNY 1847) (No 7,434).

80. The Yucatan, 30 F Cas 893 (SD Fla 1847) (No 18,194).

81. The Harvest, $11 \mathrm{~F}$ Cas 726 (D Mass 1848) (No 6,176).

82. The Brewster, 4 F Cas 82 (SD Fla 1848) (No 1,852).

83. The H B Foster, $11 \mathrm{~F}$ Cas 948 (SDNY 1848) (No 6,290).

84. Bethel $v$ The Euphrasia, 8 F Cas 813 (SD Fla 1848) (No 4,545).

85. The Millinocket, 17 F Cas 391 (SD Fla 1848) (No 9,609).

86. Raft of Spars, 20 F Cas 173 (SDNY 1849) (No 11,529).

87. Boardman $v$ The Bethel, 3 F Cas 778 (SDNY 1849) (No 1,585).

88. Union Tow-Boat Co v The Delphos, $24 \mathrm{~F}$ Cas 700 (ED La 1849) (No 14,400).

89. The Huntress, 12 F Cas 979 (ED Pa 1850) (No 6,912).

90. Geiger $v$ The Mount Washington, 17 F Cas 925 (SD Fla 1851) (No 9,887).

91. Bethel $v$ The John $Æ$ Albert, 13 F Cas 653 (SD Fla 1851) (No 7,333).

92. Acosta $v$ The Merchant, 17 F Cas 35 (SD Fla 1851) (No 9,435).

93. The Telamon, 23 F Cas 834 (SD Fla 1852) (No 13,820).

94. McGinnis $v$ The Pontiac, 16 F Cas 112 (D Ohio 1852) (No 8,801).

95. Montgomery $v$ The T P Leathers, 17 F Cas 640 (ED La 1852) (No 9,736).

96. Greene $v$ The F A Everett, 8 F Cas 946 (SD Fla 1853) (No 4,603).

97. The Nathaniel Kimball, 17 F Cas 1201 (SD Fla 1853) (No 10,033).

98. Butterworth $v$ The Washington, 4 F Cas 925 (SDNY 1853) (No 2,253). 
99. Brooks $v$ The William Penn, 4 F Cas 312 (CC D SC 1853) (No 1,965).

100. The Cimbus, 5 F Cas 686 (SD Fla 1853) (No 2,718).

101. Williamson $v$ The Alphonso, 30 F Cas 4 (CC D Mass 1853) (No 17,749).

102. Emerson $v$ The Pandora, 8 F Cas 638 (ED La 1853) (No 4,442).

103. Hennessey $v$ The Versailles, 11 F Cas 1128 (CC D Mass 1853) (No 6,365).

104. The Scotsman, 21 F Cas 797 (SD Fla 1853) (No 12,515).

105. Packer $v$ The Marathon, 16 F Cas 695 (SD Fla 1853) (No 9,058).

106. The Robert Morris, 20 F Cas 876 (SD Fla 1853) (No 11,893).

107. Sturtevant $v$ The George Nicholaus, 23 F Cas 333 (ED La 1853) (No 13,578).

108. Williams $v$ The Jenny Lind, 29 F Cas 1365 (ED La 1853) (No 17,723).

109. The Beed v Elizabeth Bruce, 8 F Cas 477 (SD Fla 1854) (No 4,358).

110. The Angeline, $1 \mathrm{~F}$ Cas 911 (SD Fla 1854) (No 385).

111. In re The Iconium, $12 \mathrm{~F}$ Cas 1154 (SD Fla 1854) (No 6,995).

112. Fraw $v$ The Athalia, 2 F Cas 75 (SD Fla 1853) (No 598).

113. Phillips $v$ United States, 19 F Cas 527 (D Conn 1854) (No 11,107).

114. Ocean Steam-Nav Co v The Revenue, 18 F Cas 561 (SDNY 1854) (No 10,413).

115. The Missouri, 17 F Cas 484 (D Mass 1854) (No 9,654).

116. The US Mail SS Co v The John Potter, 28 F Cas 818 (SDNY 1855) (No 16,792a).

117. The Independence, 13 F Cas 7 (CC D Mass 1855) (No 7,014).

118. Bennett $v$ The Tevere, 3 F Cas 234 (SD Fla 1855) (No 1,325).

119. Baker $v$ The Ellen Hood, 8 F Cas 515 (SD Fla 1855) (No 4,377).

120. Blunt $v$ The Frank, 3 F Cas 759 (SDNY 1855) (No 1,577).

121. The DM Hall $v$ The John Land, 7 F Cas 770 (N D Cal 1855) (No 3,939).

122. Adams $v$ The Ashburton, 2 F Cas 14 (SD Fla 1856) (No 575).

123. Geiger $v$ The Mary Hale, 16 F Cas 985 (SD Fla 1856) (No 9,213).

124. The Attacapas, 2 F Cas 191 (D Mass 1856) (No 637).

125. The Albus, 1 F Cas 323 (SD Fla 1856) (No 148).

126. The Diadem, 7 F Cas 632 (SD Fla 1856) (No 3,874).

127. Curry v The Crown, 6 F Cas 917 (SD Fla 1857) (No 3,450).

128. Spencer $v$ The Charles Avery, 22 F Cas 917 (SD Ohio 1857) (No 13,232).

129. The Philah, 19 F Cas 494 (SD Fla 1857) (No 11,091a). 
130. Caste $v$ The Helen E Booker, 11 F Cas 1039 (SD Fla 1857) (No 6,330).

131. The Underwriter, 24 F Cas 528 (SDNY 1857) (No 14,341).

132. Virden $v$ The Caroline, 28 F Cas 1219 (D Del 1857) (No 16,956).

133. The Rockland, 20 F Cas 1076 (SD Fla 1858) (No 11,981).

134. Curtis v Quantity of Wearing Apparel, 6 F Cas 1007 (SDNY 1858) (No 3,505).

135. The Sierra Nevada, 22 F Cas 105 (SD Fla 1858) (No 12,846).

136. Geiger v Montserat, 17 F Cas 649 (SD Fla 1858) (No 9,740).

137. Roberts $v$ The Sultan, 23 F Cas 378 (SD Fla 1858) (No 13,601).

138. Lamar $v$ The Penelope, 14 F Cas 977 (E D SC 1858) (No 8,007).

139. The Osteonthe, 18 F Cas 893 (SD Fla 1858) (No 10,608a).

140. Roberts $v$ The Mimi, 17 F Cas 436 (SD Fla 1859) (No 9,627a).

141. The Nathan Hannan, 17 F Cas 1184 (SD Fla 1859) (No 10,029).

142. Coffin v The John Shaw, 5 F Cas 1193 (CC D NH 1859) (No 2,949).

143. Blagg $v$ The E M Bicknell, 3 F Cas 555 (SD Ohio 1859) (No 1,476).

144. Lowe $v$ The Indian Hunter, 13 F Cas 30 (SD Fla 1859) (No 7,024).

145. The John E Clayton, 13 F Cas 666 (CC SDNY 1859) (No 7,338).

146. The Susan, 23 F Cas 440 (D Mass 1859) (No 13,630).

147. The Mulhouse, 17 F Cas 962 (SD Fla 1859) (No 9,910).

148. The Mary Coe, 16 F Cas 972 (SD Fla 1860) (No 9,204).

149. The Eliza Mallory, 8 F Cas 492 (SD Fla 1860) (No 4,365).

150. Rutter $v$ The Ferris, 21 F Cas 99 (ED Pa 1860) (No 12,178).

151. Sturgis $v$ The Joseph Johnson, 23 F Cas 323 (SDNY 1860) (No 13,576).

152. The Huntsville, 12 F Cas 996 (E D SC 1860) (No 6,916).

153. Pent $v$ The Ocean Belle, 19 F Cas 200 (SD Fla 1861) (No 10,961).

154. Sawyer $v$ The Maria Pike, 16 F Cas 740 (SD Fla 1861) (No 9,081).

155. Strout $v$ The Cuba, 23 F Cas 262 (SDNY 1861) (No 13,549).

156. Adams $v$ The Island City, $1 \mathrm{~F}$ Cas 119 (2d Cir 1859), affd, 66 US 121 (1861) (No 55).

157. The Czarina, 6 F Cas 1106 (CC D Mass 1862) (No 3,531).

158. W Transp Co v The Great Western, 29 F Cas 777 (N D N Y 1862) (No 17,443).

159. The Thomas Hunt, 22 F Cas 1140 (D Conn 1862) (No 13,326). 
160. Sturgis $v$ The Edward, 23 F Cas 322 (D N Y 1863) (No 13,575).

161. The James T Abbott, 13 F Cas 340 (D Mass 1864) (No 7,202).

162. Winso v The Cornelius Grinnell, 30 F Cas 309 (SDNY 1864) (No 17,883).

163. Towle $v$ The Great Eastern, 24 F Cas 75 (SDNY 1864) (No 14,110).

164. The Ida L Howard, 12 F Cas 1163 (D Mass 1865) (No 6,999).

165. The Zealand, 30 F Cas 917 (D Mass 1865) (No 18,205).

166. The Charles Henry, 5 F Cas 509 (EDNY 1865) (No 2,617).

167. The Caroline Nesmith, 5 F Cas 99 (SD Fla 1865) (No 2,423).

168. The Harwood, 11 F Cas 763 (SD Fla 1866) (No 6,186).

169. The Albion Lincoln, 1 F Cas 312 (D Mass 1866) (No 144).

170. The Georgiana, 10 F Cas 249 (D Mass 1866) (No 5,355).

171. Holmes $v$ The Joseph $C$ Griggs, 12 F Cas 417 (EDNY 1866) (No 6,640).

172. Llewellyn $v$ Two Anchors ↔) Chains, 15 F Cas 711 (EDNY 1866) (No 8,428).

173. The Joseph A Davis, 13 F Cas 1132 (SD Fla 1866) (No 7,534).

174. The M B Stetson, 16 F Cas 1272 (D Mass 1866) (No 9,363).

175. The W F Garrison, 29 F Cas 848 (D Mass 1867) (No 17,475).

176. The Lovett Peacock, 15 F Cas 1003 (D Mass 1867) (No 8,555).

177. Bowley v Goddard, 3 F Cas 1072 (D Mass 1867) (No 1,736).

178. The Saragossa, 21 F Cas 426 (SDNY 1867) (No 12,335).

179. The Saragossa, 21 F Cas 425 (SDNY 1867) (No 12,334).

180. The Merrimac, 17 F Cas 117 (EDNY 1867) (No 9,473).

181. Seamen $v$ Erie Ry Co, 21 F Cas 918 (EDNY 1868) (No 12,582).

182. The John G Paint, 13 F Cas 678 (EDNY 1868) (No 7,346).

183. The George Gilchrist, $10 \mathrm{~F}$ Cas 213 (D Mass 1868) (No 5,333).

184. The S L Davis, 22 F Cas 318 (CC SDNY 1868) (No 12,939).

185. Johnson $v$ The Industry, 13 F Cas 749 (D Cal 1868) (No 7,391).

186. Pope $v$ The Sapphire, 19 F Cas 1044 (D Cal 1869) (No 11,276).

187. The Annie Leland, 1 F Cas 978 (D Mass 1869) (No 421).

188. The Gary v The Sherman, 10 F Cas 61 (D SC 1869) (No 5,259).

189. The Delaware, 7 F Cas 393 (SDNY 1869) (No 3,761).

190. The Albert Gallatin, 1 F Cas 305 (S D Ala 1869) (No 140).

191. The W D B, 29 F Cas 480 (D Me 1869) (No 17,306).

192. The Blackwall, 77 US (10 Wall) 1 (1869). 
193. The Saxon, 21 F Cas 595 (EDNY 1870) (No 12,412).

194. The Birdie, 3 F Cas 439 (CC SDNY 1870) (No 1,432).

195. Seven Coal Barges, 21 F Cas 1096 (D Ind 1870) (No 12,677).

196. The Cheeseman $v$ Two Ferryboats, 5 F Cas 528 (S D Ohio 1870) (No 2,633).

197. Hall $v$ The Paquet Bot de Cayenne, 11 F Cas 243 (CC D Del 1870) (No 5,941).

198. The Rebecca Clyde, 20 F Cas 384 (SDNY 1871) (No 11,621).

199. The Virginia, 28 F Cas 1222 (CC SD Ill 1871) (No 16,957).

200. The IL Bowen, 13 F Cas 635 (SDNY 1871) (No 7,322).

201. Fifty Thousand Feet of Timber, 9 F Cas 47 (D Mass 1871) (No 4,783).

202. The Senator, 21 F Cas 1076 (ED Mich 1872) (No 12,664).

203. The Minnie Miller, 17 F Cas 451 (EDNY 1872) (No 9,638).

204. The Bolivar $v$ The Chalmette, 3 F Cas 818 (ED Tex 1872) (No 1,611).

205. The Clotilda, 5 F Cas 1075 (D Me 1872) (No 2,903).

206. The Wexford, 29 F Cas 847 (EDNY 1872) (No 17,472).

207. The Anna, 1 F Cas 931 (CC EDNY 1873) (No 401).

208. The Northwester, 18 F Cas 387 (SD Fla 1873) (No 10,333).

209. The Mississippi, 17 F Cas 478 (SD Fla 1874) (No 9,651).

210. The Pennsylvania, 19 F Cas 176 (ED Pa 1874) (No 10,945).

211. The Puritan, 20 F Cas 70 (EDNY 1875) (No 11,474).

212. Browning $v$ Baker, 4 F Cas 453 (ED Va 1875) (No 2,041).

213. The Capt Geo W Wright, 5 F Cas 44 (EDNY 1875) (No 2,393).

214. The Costa Rica, 6 F Cas 609 (D Cal 1876) (No 3,262).

215. The Ontario, 18 F Cas 736 (EDNY 1876) (No 10,541).

216. Baker $v$ Hemenway, 2 F Cas 463 (D Mass 1876) (No 770).

217. Curry v The Loch Goil, 6 F Cas 995 (SD Fla 1877) (No 3,495).

218. The D W Vaughan, 8 F Cas 202 (EDNY 1877) (No 4,222).

219. In re One Anchor @) Chain, 18 F Cas 698 (D Mass 1877) (No 10,517).

220. Twenty-Three Bales of Cotton, 24 F Cas 419 (EDNY 1877) (No 14,824).

221. Sonderburg v Ocean Towboat Co, 22 F Cas 795 (D La 1878) (No 13,175).

222. The Colima, 6 F Cas 98 (D Cal 1878) (No 2,996).

223. Mattingly $v$ Three Hundred $\uplus$ Fifty-Seven Bales of Cotton, 16 F Cas 1142 (WD Tenn 1878) (No 9,294).

224. The Carl Schurz, 5 F Cas 84 (WD Tenn 1879) (No 2,414).

225. Ensign $v$ The Peerless, 8 F Cas 725 (ED Wisc 1879) (No 4,494).

226. The Allegiance, 1 F Cas 431 (D Or 1879) (No 207). 
227. Fulmer $v$ Patterson, 9 F Cas 992 (ED Pa 1879) (No 5,152).

228. Corwin $v$ The Barge Jonathan Chase, 2 F 268 (EDNY 1880).

229. Atlas S S Co v S S Colon, 4 F 469 (CC SDNY 1880).

230. Ehrman v S S Swiftsure, 4 F 463 (D Md 1880).

231. The Bark Lovetand, five F 105 (SDNY 1880).

232. Murphy v Schooner Mary S Hontvet, 4 F 920 (D NH 1880).

233. Coffin $v$ The Brig Akbar, 5 F 456 (EDNY 1880).

234. Moore $v$ The Caribon, 17 F Cas 669 (SD Fla 1880) (No 9,753a).

235. Murphy v Ship Suliote, 5 F 99 (CC D La 1880).

236. Pendleton $v$ Steamboat Reuben Potter, 3 F 812 (D RI 1880).

237. The Mary E Long, 7 F 364 (ED Pa 1881).

238. The Henry Frank, 11 F 763 (CC ED La 1881).

239. The Plymouth Rock, 9 F 413 (SDNY 1881).

240. The Key West, 11 F 911 (CC ED La 1881).

241. The Levi Davis, 9 F 715 (EDNY 1881).

242. The BC Terry, 9 F 920 (S D Ga 1881).

243. The Old Natchez, 9 F 476 (SD Miss 1881).

244. The Sandringham, $10 \mathrm{~F} 556$ (ED Va 1882).

245. The Hyderabad, $11 \mathrm{~F} 749$ (ED Wis 1882).

246. The Leipsic, 10 F 585 (CC SDNY 1882).

247. The Mary E Dana, 17 F 353 (ED Va 1882).

248. Cargo from Wreck of Bark Edwards, 12 F 508 (SD Fla 1882).

249. Scott $v$ The Clara E Bergen, 21 F Cas 816 (D SC 1882)

(No 12,526a).

250. Anderson $v$ The Edam, 13 F 135 (EDNY 1882).

251. French $v$ The Excelsior, $48 \mathrm{~F} 749$ (ED Va 1882).

252. The Arendal, 14 F 580 (ED Pa 1882).

253. NY Harbor $\oplus$ Towboat Co v Grain Elevators Am « Egypt (The Rialto), 15 F 124 (EDNY 1882).

254. Id, 15 F 124.

255. Id, 15 F 124.

256. The Carrie, 88 F 983 (ED Va 1883).

257. Muntz v Raft of Timber, 15 F 555 (ED La 1880).

258. The Marie Anne, 48 F 742 (ED Va 1883).

259. The Annie Henderson, 15 F 550 (D Conn 1883).

260. The Neto, 15 F 819 (SD Fla 1883).

261. The Sophia Hanson, 16 F 144 (EDNY 1883).

262. The Dolcoath, 16 F 264 (SD Fla 1883).

263. The Hesper, 18 F 692 (ED Tex 1883), affd, 122 US 256 (1887).

264. The Connemara v Cooper, 108 US 352 (1882).

265. The Cyclone, 16 F 486 (SDNY 1883).

266. Long $v$ The Tampico, 16 F 491 (SDNY 1880).

267. The Egypt, 17 F 359 (ED Va 1883). 
268. The $C \uplus$ C Brooks, 17 F 548 (D NJ 1887).

269. Good Intent Tow-Boat Co v Atl Mut Ins Co of NY, 109 US 110 (1883).

270. The Maggie Ellen, 19 F 221 (EDNY 1883).

271. The Flower City, 16 F 866 (NDNY 1883).

272. The Florida, 22 F 617 (SD Ga 1884).

273. The Lahaina, 19 F 923 (EDNY 1884).

274. The Daniel Steinman, 19 F 918 (EDNY 1884).

275. The Guadalupe, $20 \mathrm{~F} 443$ (D Tex 1883).

276. Howard $v$ The Manhattan No 12, 20 F 391 (D Conn 1884).

277. Id, $20 \mathrm{~F} 391$.

278. The Rosedale, 20 F 447 (D Conn 1883).

279. The Cairnsmore, 20 F 519 (D Or 1884).

280. The Young America, 20 F 926 (D NJ 1884).

281. The Katie Collins, 21 F 409 (D Del 1884).

282. The Queen of the Pacific, 21 F 459 (D Or 1884).

283. The Mabel, 22 F 543 (D Cal 1884).

284. Tessier $v$ The Lee, $24 \mathrm{~F} 47$ (CCED La 1884).

285. The Indiana, $22 \mathrm{~F} 925$ (ED Pa 1885).

286. The Rio Grande, 22 F 914 (SDNY 1885).

287. Scott $v$ Seventy-Five Tons of Pig-Iron, 23 F 197 (D Conn 1885).

288. The Alaska, 23 F 597 (SDNY 1885).

289. The Perseverance, 27 F 478 (EDNY 1885).

290. Winslow $v$ The Baker, 25 F 771 (CCSDNY 1885), modifying 23 F 109 (SDNY 1885).

291. Coffin v The OM Hitchcock, 25 F 777 (SDNY 1885).

292. The FI Merryman, 27 F 313 (EDNY 1886).

293. The Maggie Willett, 27 F 519 (D Mass 1886).

294. Russell v The Oregon, 27 F 871 (SDNY 1886).

295. Wilson $v$ Winchester, 30 F 204 (EDNY 1886).

296. Bergantz $v$ The Cloud, 29 F 272 (ED Pa 1886).

297. Denmead v The Alice M Minot, 30 F 212 (ED Va 1887).

298. Estill $v$ The Fairfield, $30 \mathrm{~F} 700$ (SD Ga 1887).

299. Baker Salvage Co v The Fannie Brown, 30 F 215 (ED Va 1887).

300. Morgan's La « TR « SS Co v De Arrotegui (The Gallego), 30 F 271 (EDNY 1887).

301. Gillespie $v$ The Mary H Hogan, 30 F 381 (EDNY 1887).

302. Tebo $v$ The Cassandra Adams, $30 \mathrm{~F} 379$ (EDNY 1887).

303. Gaynor $v$ The Gler, 31 F 425 (SD Ga 1887).

304. Sibley $v$ The Mira A Platt, 31 F 572 (SD Ala 1887).

305. Young $v$ The Cherokee, 31 F 167 (D SC 1887).

306. Vierow $v$ The Rose, 31 F 176 (EDNY 1887).

307. Tebo $v$ The James A Garfield, 31 F 175 (EDNY 1887). 
308. Beebe $v$ The Wisconsin, $32 \mathrm{~F} 111$ (CCEDNY 1887), affg, $30 \mathrm{~F}$ 846 (EDNY 1887).

309. Driscoll v The Straits of Gibraltar, 32 F 297 (D NJ 1887).

310. Galveston SS «) Lighter Co v The RD Bibber, 33 F 55 (ED Tex 1887).

311. Baker Salvage Co v The Taylor Dickson, 33 F 886 (ED Va 1888).

312. Millard v New Orleans Natl Storage Co (The Louisiana), 34 F 663 (SDNY 1888).

313. Id, 34 F 663.

314. The Lone Star, 34 F 807 (EDNY 1888).

315. Barrett $v$ The New York, 34 F 922 (EDNY 1888).

316. Wilson $v$ The Bessie Whiting, 35 F 79 (EDNY 1888).

317. Baker Salvage Co $v$ The Kimberley, 40 F 289 (ED Va 1888).

318. Bos Tow-Boat Cov The Andrew Adams, 36 F 205 (D Mass 1888).

319. Compagnie Bordelaise de Navigation à Vapeur v The California, 36 F 563 (EDNY 1888).

320. The SS Samana $v$ The Erin, 36 F 712 (EDNY 1888).

321. L'Hommedieu $v$ The Carondelet, 36 F 714 (EDNY 1888).

322. Seamen $v$ The Benison, 36 F 793 (SDNY 1888).

323. La ↔) TR «) SS Co v The Pomona, 37 F 444 (D SC 1889).

324. Spreckles $v$ The Brussels, 38 F 524 (ND Cal 1889).

325. Santos $v$ The Cachemire, 38 F 518 (D SC 1889).

326. Gibson $v$ The Alice Clark, 39 F 621 (SD Ga 1889).

327. McDonald $v$ The Resolute, 38 F 923 (WD Pa 1889).

328. SC Steam-Boat Co v The Nellie Floyd, 39 F 221 (D SC 1889).

329. Sullivan $v$ The Vanloo, 39 F 570 (EDNY 1889).

330. McCauley $v$ The Rudolph, 39 F 331 (SDNY 1889).

331. Boyes $v$ The Avoca, 39 F 567 (EDNY 1889).

332. McCaldin $v$ The Labrador, 39 F 503 (EDNY 1889).

333. Stone $v$ The Jewell, 41 F 103 (SD Ala 1889).

334. The Joseph Laughlin $v$ The James Ramsay, 40 F 909 (SDNY 1890).

335. Id, 40 F 909.

336. Spreckles $v$ The Kenilworth, 41 F 523 (ND Cal 1890).

337. Id, 41 F 523.

338. Id, 41 F 523.

339. Luckenbach $v$ The Wallace, 41 F 894 (EDNY 1890).

340. The Albany, 42 F 64 (D Mass 1890).

341. Hamburg-Am Packet Co v The Italia, 42 F 416 (EDNY 1890).

342. Bywater v Raft of Piles, 42 F 917 (D Wash 1890).

343. Tebo $v$ The Jarlen, 43 F 176 (EDNY 1890). 
344. Bowers $v$ The European, $44 \mathrm{~F} 484$ (SD Fla 1890).

345. Balt e) ORR Co $v$ The Holland, 44 F 362 (EDNY 1890).

346. Scott $v$ City of Worcester, 42 F 913 (D Conn 1890), affd, 45 F 119 (CCD Conn 1891).

347. New Eng Terminal Co v The M Vandercook, 45 F 262 (D Conn 1891).

348. Candee v Sixty-Eight Bales Cotton, 48 F 479 (SD Ala 1891).

349. Walsh $v$ Scows 16 Æ) 24, 45 F 9019 (SDNY 1891).

350. Atl e) CSS Co v The Tancarville, 45 F 903 (SDNY 1891).

351. The Isaac May, 46 F 79 (NDNY 1891).

352. Easton e) Amboy Co $v$ The Scow No 19, 46 F 406 (SDNY 1891).

353. Gunby v Baker-Whitley Co (The Khio), 46 F 207 (D Md 1891).

354. Am Petroleum Co $v$ The Veendam, 46 F 489 (SDNY 1891).

355. Millard $v$ The Rahway, 46 F 809 (EDNY 1891).

356. Id, 46 F 809.

357. Sharpley $v$ The Calvin S Edwards, 46 F 815 (EDNY 1891).

358. Bartley $v$ The William A Taylor, $47 \mathrm{~F} 70$ (EDNY 1891).

359. Sweeting $v$ The Tennasserim e) Cargo, 47 F 119 (SD Fla 1891).

360. Spreckels $v$ The Don Carlos, 47 F 746 (ND Cal 1891).

361. Spreckels $v$ The Jessomene, 47 F 903 (ND Cal 1891).

362. Hall $v$ The Lucy P Miller, 48 F 121 (SDNY 1891).

363. Hond «) CASS Co v $\$ 9,500$ In Silver Specie (The Aguan), 48 F 320 (SDNY 1891).

364. Hall $v$ The Bay of Naples, 48 F 737 (CCSDNY 1891).

365. Hamilton $v$ The Kaaterskill, 48 F 701 (SDNY 1892).

366. The Eleanor $v$ The Thomas W Haven, 48 F 842 (D SC 1892).

367. Propeller Tow-Boat Co v The Agnes I Grace, 49 F 662 (SD Ga 1892).

368. Russell $v$ The Tregurno, 50 F 946 (SD Fla 1892).

369. E 4 AR Co v The Lydia, 49 F 666 (EDNY 1892).

370. Sheldrake $v$ The Chatfield, 52 F 479 (ED Va 1892).

371. Id, 52 F 479.

372. Stebbins v Five Mud-Scows, 50 F 227 (SDNY 1892).

373. Murray $v$ The John Swan, 50 F 447 (SDNY 1892).

374. Jones $v$ Car Float No 5, 50 F 573 (SDNY 1892).

375. Luckenback $v$ Scows 3 «) 16, 50 F 570 (SDNY 1892).

376. Millard v The Despatch, 50 F 611 (SDNY 1892).

377. Edwards $v$ The Alexander Elder (The Relief), 51 F 252 (D Md 1892).

378. Upton $v$ The Charles Wetmore, 51 F 449 (D Or 1892).

379. Lewis $v$ A Lot of Whalebone, 51 F 916 (ND Cal 1892).

380. Robertson $v$ The Wellington, 52 F 605 (ND Cal 1892). 
381. Rogers $v$ Two Barges «) A Cargo of Coal, 53 F 284 (SDNY 1892).

382. Chapman Derrick $\uplus$ Wrecking Co v Henry R Tilton, 53 F 139 (SDNY 1892).

383. Millard v The Lighter No 14, 53 F 143 (SDNY 1892).

384. Davis $v$ Transfer No 1 ↔) Float No 23, 53 F 610 (SDNY 1893).

385. Seville $v$ The Georgia, 53 F 933 (SDNY 1893).

386. The River Belle, 153 F 475 (SDNY 1893).

387. Wood v Burg, 54 F 197 (4th Cir 1892).

388. Hollenbeck $v$ The City of Atlanta, 56 F 252 (SDNY 1893).

389. McCaldin $v$ The Richard S Garrett, 55 F 90 (SDNY 1893).

390. Millard v Barnegat, 55 F 92 (SDNY 1893).

391. Demarest $v$ The Helen F Robbins, 55 F 1014 (EDNY 1893).

392. The Sirius $v$ Cedros Island Min «) Mill Co, 57 F 851 (9th Cir 1893).

393. The Pelican, 158 F 183 (ED Mich 1893).

394. Clyde SS Co v The William Smith, 59 F 615 (SDNY 1893).

395. Compagnie Commerciale de Transp à Vapeur Française $V$ Charente SS Co, 60 F 921 (5th Cir 1893), modifying 55 F 93 (ED La 1893).

396. Bates $v$ The OC DeWitt, 59 F 620 (EDNY 1894).

397. Bristol City Lime Co v The Agnes Manning, 59 F 481 (EDNY 1894).

398. Tebo v City of NY (The Public Bath No 13), 61 F 692 (SDNY 1894).

399. Neal $v$ The Elena $G$, 61 F 519 (ED Pa 1894).

400. Clarke $v$ The Rita, 62 F 761 (5th Cir 1894).

401. Parsons v Rockwell (The Phoenix), 62 F 487 (4th Cir 1894).

402. Ocean SS Co v The Chinese Prince, 61 F 697 (ED SC 1894).

403. Natl SS Co v The Hekla, 62 F 941 (EDNY 1894).

404. Dailey $v$ The Mary Freeland, 62 F 943 (EDNY 1894).

405. Wright $v$ The Felix, 62 F 620 (ED Pa 1894).

406. Munson $v$ The Vila, 63 F 1017 (EDNY 1894).

407. Alexander $v$ Car Floats Nos 1, 3, 4, e) 5, 64 F 887 (SDNY 1894).

408. The Rescue $v$ The George B Roberts, 64 F 139 (ED Pa 1894).

409. Janes $v$ Sweeting (The Oxford), 66 F 590 (5th Cir 1895), modifying 66 F 584 (SD Fla 1895).

410. De Leon v Leitch, 65 F 1002 (ED La 1895).

411. Knickerbocker Steam-Towage Co v City of Haverhill, $66 \mathrm{~F}$ 159 (SDNY 1895).

412. Hein $v$ The Beaconsfield, $67 \mathrm{~F} 144$ (SD Ala 1895).

413. McGraw Transp Co v The Spokane, 67 F 254 (ED Wisc 1895). 
414. The Meriulio, 68 F 935 (SDNY 1895).

415. Tice $v$ The Hudson, 68 F 936 (SDNY 1895).

416. Marcussen v Saunders (The Amity), 69 F 110 (5th Cir 1895).

417. Weir v Price (The Elmbank), 69 F 104 (9th Cir 1895).

418. Royal W India Co v City of Para, 69 F 479 (ED Va 1895).

419. Neth-Am Steam Nav Cov The Dania, 70 F 398 (EDNY 1895).

420. Luckenbach $v$ The North Erin, 71 F 430 (EDNY 1895).

421. Natl SS Co v La Hesbaye, 71 F 742 (DNY 1896).

422. Thomas $v$ The Florence, 71 F 527 (2d Cir 1896).

423. The LW Perry, 71 F 745 (ED Wisc 1896).

424. Grummond $v$ The Burlington, 73 F 258 (ED Mich 1896).

425. Burger $v$ The Moonlight, 72 F 282 (EDNY 1896).

426. New Orleans, BRM $\oplus$ CA SS Co v Weltzin (The Gambetta), 74 F 259 (5th Cir 1896).

427. Intl Nav Co v The Obdam, 72 F 543 (D NJ 1896).

428. Belgian Am Mar Co v The Great Northern, 72 F 678 (ED Va 1896).

429. Morgan's L ↔) TR «) SS Co v The Alaska, 75 F 430 (EDNY 1896).

430. Flannery $v$ The General Knox, 74 F 575 (EDNY 1896).

431. Lewis $v$ Atchison (The Alamo), 75 F 602 (5th Cir 1896).

432. Brown $v$ The Ranger, 75 F 688 (EDNY 1896).

433. Canadian-Australian SS Line V The Strathnevis, 76 F 855 (D Wash 1896).

434. Id, 76 F 855.

435. Pyman $v$ Clarke (The Elfrida), 77 F 754 (5th Cir 1896).

436. Rogers $v$ The OC Hanchett, 76 F 1003 (2d Cir 1896).

437. The Waverly, 78 F 191 (ED Wisc 1897).

438. Puget Sound Tugboat Co v The City of Puebla, 79 F 982 (D Wash 1897).

439. Pac Imp Co v Hatch (The Monticello), 81 F 211 (ND Cal 1897).

440. Noriea $v$ Castellano (The Laura), 83 F 311 (5th Cir 1897).

441. The RR Rhodes $v$ Fay, 82 F 751 (6th Cir 1897).

442. Jenks Ship-Bldg Co v Wallace \& Cunningham Transit Co (The HE Runnells), 82 F 755 (6th Cir 1897).

443. The Haxby v Merritt's Wrecking Org, 83 F 715 (4th Cir 1897).

444. Flannery $v$ The Dayton, 84 F 678 (EDNY 1897).

445. Crocker v The Arkansas, 84 F 361 (D NJ 1897).

446. The Brandywine, 87 F 652 (4th Cir 1898).

447. Duff $v$ Merrit (The Lamington), 86 F 675 (2d Cir 1898).

448. Intl Nav Co v The St Paul, 86 F 340 (2d Cir 1898), affg, 82 F 104 (SDNY 1897). 
449. Commercial Towboat Co v The George W Clyde, 86 F 665 (2d Cir 1898).

450. The Roman Prince, 88 F 336 (SDNY 1898).

451. Kasbek SS Co v The TF Oakes, 87 F 229 (EDNY 1898).

452. Whitmire $v$ Cobb, 88 F 91 (5th Cir 1898).

453. The Rita, 88 F 523 (SDNY 1898).

454. The Niagara, $89 \mathrm{~F} 1000$ (SDNY 1898).

455. Id, 89 F 1000.

456. The Canada, 92 F 196 (D Alaska 1899).

457. Ulster SS v Cape Fear Towing « Transp Co, 94 F 214 (5th Cir 1899).

458. Peacock $v$ Three Million Feet of Lumber, 93 F 983 (ND Cal 1899).

459. The Boyne, $98 \mathrm{~F} 444$ (ED Va 1899).

460. The Sir Robert Fernie, 96 F 348 (D Wash 1899).

461. The Trefusis, 98 F 314 (5th Cir 1899).

462. United States v Morgan, 99 F 570 (4th Cir 1900).

463. The Peru, 99 F 783 (ED Pa 1900).

464. The Winifred, 102 F 988 (SDNY 1900).

465. The Grace Dollar, 103 F 665 (ND Cal 1900).

466. The Alexandra, 104 F 904 (D SC 1900).

467. The New Camelia, 105 F 637 (5th Cir 1900).

468. The Catalina, 105 F 633 (5th Cir 1900).

469. The IJ Merritt, 106 F 970 (SDNY 1901).

470. The Alice Blanchard, 106 F 238 (ND Cal 1901).

471. The Barge No 127, 113 F 529 (D RI 1901).

472. The Penobscott, 106 F 419 (4th Cir 1901).

473. The Elm Branch, 106 F 952 (D Wash 1901).

474. The Santa Ana, 107 F 527 (D Wash 1901).

475. The Coya, 108 F 413 (SDNY 1901).

476. Simpson v Dollar, 109 F 814 (9th Cir 1901).

477. The Gov Ames, 108 F 969 (5th Cir 1901).

478. The Bremen, 111 F 228 (SDNY 1901).

479. Id, $111 \mathrm{~F} 228$.

480. The James Turpie, 113 F 700 (D NJ 1902).

481. The Independent, 113 F 702 (D RI 1902).

482. Hume v J D Spreckles «) Bros Co, 115 F 51 (9th Cir 1902).

483. The William P Hood, 114 F 983 (D RI 1902).

484. The Josephus, 116 F 124 (D RI 1902).

485. Merritt $\oplus$ Chapman Derrick 4 Wrecking Co v North German Lloyd, 120 F 17 (SDNY 1902).

486. $I d, 120 \mathrm{~F} 17$.

487. Id, $120 \mathrm{~F} 17$.

488. The Flottbek, 118 F 954 (9th Cir 1902). 
489. Gilchrist Transp Co v 110,000 Bushels of No 1 Northern Wheat, 120 F 432 (WDNY 1903).

490. Scows No 21 «) 59, 121 F 430 (SDNY 1903).

491. The Pinmore, 121 F 423 (D Wash 1903).

492. The Lyman M Law, 122 F 816 (D Me 1903).

493. Id, 122 F 816.

494. The Thomas Morgan, 123 F 781 (D SC 1903).

495. The Apache, 124 F 905 (ED SC 1903).

496. The Ereza, $124 \mathrm{~F} 659$ (ED Pa 1903).

497. The Joseph Stickney, 127 F 763 (SDNY 1904).

498. The Ira A Allen, $128 \mathrm{~F} 172$ (SDNY 1904).

499. The Dumper No 8, 129 F 98 (2d Cir 1904).

500. The Edith L Allen, 129 F 209 (2d Cir 1904), modifying, 122 F 729 (SDNY 1904).

501. Rees v United States, 134 F 146 (ND Cal 1904).

502. The Eliza Strong, 130 F 99 (6th Cir 1904).

503. The I Emory Owen, 128 F 996 (ED Wisc 1904).

504. Perriam v Pac Coast Co, 133 F 140 (9th Cir 1904).

505. The Fred E Scammell, 133 F 608 (SDNY 1904).

506. The Hughes Brothers \&) Bangs, 135 F 746 (2d Cir 1904).

507. The Lottie E Hopkins, 133 F 405 (D Me 1904).

508. The Marcus Hook, 135 F 744 (2d Cir 1904).

509. McWilliams $v$ City of NY, 134 F 1015 (SDNY 1904).

510. The Theta, 135 F 129 (SDNY 1905).

511. The John Fleming, 136 F 486 (SDNY 1905), affd, 144 F 1021.

512. The America, 136 F 510 (D NJ 1905).

513. The Cottage City, 136 F 496 (WD Wash 1905).

514. The Santurce, 136 F 682 (SDNY 1905).

515. The Toledo, $136 \mathrm{~F} 959$ (SDNY 1905).

516. The Car Float, 138 F 435 (SDNY 1905).

517. James Clark Co v Steam Ferryboat Columbia, 26 App DC 85 (DC Cir 1905).

518. The South Bay, 139 F 273 (WD Wash 1905).

519. The Edith L Allen, $139 \mathrm{~F} 888$ (SDNY 1905).

520. The Banes, 147 F 192 (2d Cir 1906).

521. The Chief, 147 F 875 (ED Pa 1906).

522. The IW Nicholas, 147 F 793 (WDNY 1906).

523. The Rebecca Shepherd, 148 F 727 (D Me 1906).

524. The Peter White, 149 F 594 (WDNY 1906).

525. Neel v Iron City Sand Co, 149 F 980 (3d Cir 1907).

526. The Devonian, $150 \mathrm{~F} 831$ (D Mass 1907).

527. The Flora Rodgers, 152 F 286 (D SC 1907).

528. The Priscilla, 153 F 476 (SDNY 1907).

529. The Priscilla, 153 F 476 (SDNY 1907). 
530. The City of Puebla, 153 F 925 (ND Cal 1907).

531. The Launberga, 154 F 959 (ED NC 1907).

532. The Myrtle Tunnel, 146 F 324 (D SC 1906).

533. The Shawmut, 155 F 476 (D SC 1907).

534. The Lizzie Crawford, 156 F 201 (ED Pa 1907).

535. The Western Star, 157 F 489 (WD Wis 1907).

536. The Gibson, 160 F 230 (SDNY 1908).

537. The Ragnarok, 158 F 694 (EDNY 1908).

538. The Indian, 159 F 20 (5th Cir 1908).

539. The Sun, 161 F 385 (SDNY 1908).

540. The Job H Jackson, 161 F 1015 (EDNY 1908).

541. The Benjamin A Van Brunt, 164 F 775 (ED Pa 1908).

542. The Carroll, 167 F 112 (4th Cir 1908).

543. The Richmond, 181 F 568 (D Mass 1909).

544. The Alaska Exploration Co v United States, $44 \mathrm{Ct} \mathrm{Cl} 392$ (Ct Cl 1909).

545. Earn Line SS Co v United States, 170 F 834 (2d Cir 1909).

546. Pac Mail SS Co v Commercial Pac Cable Co, 173 F 28 (9th Cir 1909).

547. The Willis A Holden, $174 \mathrm{~F} 5$ (9th Cir 1909).

548. The Ciudad de Reus, 176 F 802 (EDNY 1909).

549. The Rockland «) Rockport Lime Co No 1, 175 F 524 (EDNY 1910).

550. The Minnie E Kelton, 181 F 237 (D Or 1910).

551. The Varzin, 180 F 892 (SDNY 1910).

552. The Jefferson, $181 \mathrm{~F} 416$ (ED Va 1910).

553. Howe $v$ City of NY, 184 F 478 (SDNY 1910).

554. The Scout, 180 F 628 (EDNY 1910).

555. The Loch Garve, 182 F 519 (9th Cir 1910).

556. The Maryland, 190 F 641 (ED Va 1911).

557. Gallagher v City of NY, 193 F 549 (EDNY 1911).

558. The Evolution, 199 F 514 (D Mass 1912).

559. Conway v City of NY, 194 F 529 (EDNY 1912).

560. The Buffalo, 194 F 900 (EDNY 1912).

561. L'Hommedieu $v$ Pa RR Co, 195 F 309 (EDNY 1912).

562. The Lowther Castle, 195 F 604 (D NJ 1912).

563. Davidson v Plummer (The Navis), 196 F 843 (D Me 1912).

564. Guindon v Cargos of Canal Boats Zenith, Adelphia, e) Gold Dust, 197 F 227 (WDNY 1912).

565. The Brina P Pendleton, $200 \mathrm{~F} 848$ (ED NC 1912).

566. The Craster Hall, 203 F 188 (SD Ga 1913).

567. The Saxoleine, 210 F 683 (EDNY 1913).

568. The Henry $R$ Tilton, 214 F 165 (D Mass 1913).

569. Albury v Cargo of the Lugano, 215 F 963 (SD Fla 1913). 
570. The Lighter PRR No 250, 209 F 493 (EDNY 1913).

571. The Neshaminy, $220 \mathrm{~F} 182$ (ED Pa 1914).

572. JM Guffey Petroleum Co v Borison, 211 F 594 (5th Cir 1914).

573. Blake v Balt e) CSS Co, 211 F 116 (5th Cir 1914).

574. Reichert $v$ Carfloat NY, NH «) HR Co No 25, 213 F 127 (EDNY 1914).

575. The Calcium, 218 F 267 (WD Wash 1914).

576. The Roanoke, 214 F 63 (9th Cir 1914).

577. The Florence, 215 F 283 (EDNY 1914).

578. The Henry Maurer, 215 F 238 (D Mass 1914).

579. The Adelaide T Carleton, 215 F 932 (D Conn 1914).

580. The Violet Blossom, 216 F 379 (D NJ 1914).

581. The Urko Mendi, 216 F 427 (ED Pa 1914).

582. The Planter, 217 F 161 (WD Wash 1914).

583. The Knickerbocker, 218 F 524 (WD Wash 1914).

584. The Lucia, 222 F 1015 (SD Fla 1915).

585. The Pleasure Bay, 226 F 55 (SD Ala 1915).

586. The Wissoe, $230 \mathrm{~F} 318$ (D Mass 1915).

587. The Alcazar, $227 \mathrm{~F} 633$ (ED NC 1915).

588. The Samuel B Hubbard, 229 F 843 (D Mass 1915).

589. Id, $229 \mathrm{~F} 843$.

590. The Celtic Chief, 230 F 753 (9th Cir 1916).

591. The Humarock, 234 F 716 (SD Ga 1916).

592. The Melderskin, 249 F 776 (SDNY 1916).

593. The Halcyon, 239 F 840 (9th Cir 1917).

594. Daniel v A Cargo of Lumber, 240 F 498 (SD Ala 1917).

595. The Livietta, 242 F 195 (5th Cir 1917).

596. The George Hawley, 242 F 473 (5th Cir 1917).

597. The Coquitlam City, 243 F 767 (WD Wash 1917).

598. The Sahara, 246 F 141 (D Md 1917).

599. The Richard F Young, 245 F 499 (ED Va 1917).

600. The Alice, 244 F 415 (4th Cir 1917).

601. Atl Mar Co v Tysell (The Georgiana), 245 F 321 (1st Cir 1917).

602. The Edilio, $246 \mathrm{~F} 470$ (ED NC 1917).

603. The Ann C Stuart, 245 F 679 (D Me 1917).

604. The Antilla, 245 F 973 (ED Va 1917).

605. The Annie Lord, 251 F 157 (D Mass 1917).

606. The Tijuca, 247 F 358 (EDNY 1918).

607. Gillican $v$ Lenoir Mach 4 Wrecking Co (The Avenger), 251 F 23 (5th Cir 1918).

608. The Rosalie Mahoney, 250 F 795 (5th Cir 1918).

609. The George W Elzey, 250 F 602 (2d Cir 1918).

610. The Joseph F Clinton, 250 F 977 (2d Cir 1918). 
611. Water Front Contracting $\uplus$ Lighterage Co v GoodwinGallagher Sand «) Gravel Co (The No 92), 252 F 117 (2d Cir 1918).

612. Manchester Liners, Ltd v United States, 53 Ct Cl 449 (Ct Cl 1918).

613. The Fordenskjold, 253 F 273 (SD Fla 1918).

614. The Portugal, 253 F 264 (SD Fla 1918).

615. The Mexico, 252 F 880 (ED Va 1918).

616. The Kia Ora, 252 F 507 (4th Cir 1918), modifed, 246 F 143 (ED Va 1917).

617. Park v Direct Nav Co, 252 F 837 (SD Tex 1918).

618. The Magnolia, 253 F 400 (ND Cal 1918).

619. The Jelling, $253 \mathrm{~F} 381$ (ED NC 1918).

620. The Kanawha $v$ The Camino, 254 F 762 (2d Cir 1918).

621. The St Charles, 254 F 509 (ED Va 1918).

622. The Teresa Accama, 254 F 637 (ED Va 1918).

623. Steamer Avalon Co v Hubbard SS Co, 255 F 854 (9th Cir 1919).

624. The Wanola, 255 F 599 (D Mass 1919).

625. The FQ Barstow, 257 F 793 (D Md 1919).

626. The Jason, $257 \mathrm{~F} 438$ (ED Va 1919).

627. The Bessie L Morse, 260 F 252 (D Me 1919).

628. The Professor Koch, 260 F 969 (D Mass 1919).

629. The Ausable, 262 F 783 (EDNY 1919).

630. The Huttonwood, 262 F 452 (EDNY 1919).

631. The Noelle, 263 F 590 (ED Va 1920).

632. Tex Co v Tex e) Gulf SS Co (The Colonel Moore), 263 F 868 (5th Cir 1920).

633. The Apalachee, 266 F 923 (ED SC 1920).

634. The Bretanier, 267 F 178 (4th Cir 1920).

635. The Copperfield, 268 F 77 (SD Fla 1920).

636. The San Diego, 269 F 978 (4th Cir 1920).

637. Potter $v$ Payne, 269 F 470 (EDNY 1920).

638. Linderup $v$ Jackson (The Ferm), 268 F 518 (5th Cir 1920).

639. The High Cliff, 271 F 202 (2d Cir 1921).

640. The Angler, $271 \mathrm{~F} 18$ (EDNY 1921).

641. The Ronald J Brown, 272 F 345 (EDNY 1921).

642. Lee $v$ City of NY, 272 F 782 (EDNY 1921).

643. The Western Pride, 274 F 920 (2d Cir 1921).

644. The Eunice, 6 Alaska 376 (D Alaska Terr 1921).

645. The Progressive, 275 F 360 (EDNY 1921).

646. Manchester Liners Ltd $v$ United States (The Manchester Brigade), 276 F 410 (ED Va 1921).

647. The Niels Nielsen, 277 F 164 (2d Cir 1921). 
648. The West Mount, 277 F 168 (2d Cir 1921).

649. United States $v$ Nelson, 276 F 706 (9th Cir 1921).

650. United States v Miles, 279 F 267 (9th Cir 1922).

651. Società Commerciale Italiana di Navigazione v Maru Nav Co, 280 F 334 (4th Cir 1922), modifying 271 F 97 (D Md 1921).

652. The Alabama, 280 F 738 (SD Tex 1922).

653. Id, $280 \mathrm{~F} 738$.

654. The Nisseqogue, $280 \mathrm{~F} 174$ (ED NC 1922).

655. The Thorvald Halvorsen, 281 F 506 (2d Cir 1922).

656. United States $v$ Aslaksen, 281 F 444 (6th Cir 1922), affd, 273 F 241 (ND Ohio 1921).

657. Falk $v$ US Shipping Bd Emergency Fleet Corp (The Olockson), 281 F 690 (5th Cir 1922).

658. The Santa Rita, $281 \mathrm{~F} 760$ (5th Cir 1922).

659. The Delmira, 283 F 441 (SD Fla 1922).

660. The Buckhannon, 1923 AMC 168 (SDNY 1922).

661. The Jean L Somerville, 1923 AMC 142 (5th Cir 1922).

662. The Impoco $v$ Imperial Oil, 287 F 400 (SDNY 1922).

663. Magnolia Petroleum Co v Natl Oil Transp Co, 1923 AMC 248 (5th Cir 1923).

664. The Lewis Brothers, 287 F 143 (SD Fla 1923).

665. Jacksonville Forwarding Co v Schooner Perry Setzer e) Cargo (The Perry Setzer), 1923 AMC 1236 (SD Fla 1923).

666. The Quoddy, 289 F 132 (D Mass 1923).

667. US Shipping Bd v Tex Co (The Brandywine), 1923 AMC 610 (5th Cir 1923).

668. The Etna, 288 F 576 (SD Tex 1923).

669. Tice Towing Line $v$ Schooner Wilbert S Bartlett, 1923 AMC 844 (EDNY 1923).

670. Foley $v$ SS Kelvinbrae, 1923 AMC 998 (SD Ga 1923).

671. The Magnetic, 293 F 94 (D NJ 1923).

672. Frederick Leyland « Co v United States, 1923 AMC 1231 (SDNY 1923).

673. Tozier $v$ The Islander, 7 Alaska 120 (D Alaska Terr 1924).

674. The Mercer, 297 F 981 (2d Cir 1924).

675. The Santa Rosa, 295 F 350 (E D SC 1924).

676. United States $v$ Cent Wharf Towboat Co (The Anahuac), 1925 AMC 318 (5th Cir 1924), affg, 1924 AMC 884 (D Me 1924).

677. Lafayette Shipping Co v Richards (City of Portland), 1924 AMC 709 (5th Cir 1924).

678. Atl Refining Co v Merritt e) Chapman Derrick «) Wrecking Co, 300 F 901 (3d Cir 1924).

679. United States $v$ SS Wisconsin Bridge, 1924 AMC 711 (SDNY 1924). 
680. Curtis Bay Towing Co v Grace SS Co (The Santa Barbara), 299 F 152 (4th Cir 1924).

681. Holbrook v Freeport Sulphur Trans Co (The Bolikow), 1924 AMC 1198 (5th Cir 1923), affg, 1923 AMC 247 (ED La 1923).

682. Merritt $\uplus)$ Chapman Derrick $\uplus)$ Wrecking Co v United States (The Naiwa), 1924 AMC 1432 (4th Cir 1924).

683. The Pendragon Castle v United States, 5 F2d 56 (2d Cir 1924).

684. Castner, Curran $\uplus$ ) Bullitt $v$ United States, 5 F2d 214 (2d Cir 1925).

685. United States v Lester F Alexander «) Co, 1925 AMC 1234 (5th Cir 1925).

686. Canadian Govt Merch Marine v United States, 1925 AMC 765 (2d Cir 1925).

687. The Florence Luckenbach, 9 F2d 1008 (ED La 1925).

688. United States v Truxillo, 1926 AMC 172 (ED La 1925).

689. Shipley $v$ SS Parismina, 1926 AMC 673 (ED La 1926).

690. Carter v Power Cruiser Normada, 1926 AMC 637 (1st Cir 1926) modifying 1924 AMC 710 (D Me 1926).

691. Prince Line, Ltd, $v$ United States, 1926 AMC 368 (Ct Cl 1926).

692. The Silverway, 14 F2d 154 (SD Ga 1926), affd, 15 F2d 648 (5th Cir 1926).

693. Bull Insular SS Co v United States (The Cornelia), $62 \mathrm{Ct} \mathrm{Cl}$ 338 (Ct Cl 1926).

694. Lockwood v Motor Boat Spitfire II, 1926 AMC 1185 (D SC 1926).

695. WE Hedger «) Co v Barge Sarasota, 1926 AMC 1135 (EDNY 1926).

696. The Independent, 14 F2d 115 (2d Cir 1926).

697. Bostrom v Honduranian SS Nicarao, 1926 AMC 1518 (ED La 1926).

698. Gilkey Bros Towing v SS Eagle, 1926 AMC 1704 (ND Cal 1926).

699. In re Lancashire Shipping, 1926 AMC 1520 (EDNY 1926).

700. Alderton Dock Yards, v SS West Nohno, 1927 AMC 42 (EDNY 1926).

701. Rand $v$ Lockwood, 16 F2d 757 (4th Cir 1927).

702. Reed v Schooner WC Smith, 1927 AMC 573 (D Mass 1927).

703. WG Coyle «) Co v SS Parnahyba, 1927 AMC 761 (ED La 1927).

704. Rodriguez v Bagalini, 17 F2d 921 (9th Cir 1927).

705. Harris v NY Cent RR Co, 1927 AMC 761 (D NJ 1927).

706. De Almadiz v Skogland 4 ) Sons, 1927 AMC 760 (5th Cir 1927), affg, 1926 AMC 1330 (ED La 1926).

707. Merritt «) Chapman Derrick « Wrecking Co v United States, 63 Ct Cl 297 (1927). 
708. The Morzhovoi, 20 F2d 265 (WD Wash 1927).

709. Roderigues v Schooner Nettie C, 1927 AMC 910 (D Mass 1927).

710. Mears Towing Co v Steamlighter Leesburg, 1927 AMC 1308 (EDNY 1927).

711. Barrett $v$ Barge Erie No 409, 1927 AMC 1308 (EDNY 1927).

712. The Emanuel Stavroudis, 23 F2d 214 (D Md 1927).

713. Atl Towing Co v SS South American, 1927 AMC 622 (SD Ga 1927), modified, 1928 AMC 148 (5th Cir 1927).

714. Barrett $v$ Scows, 1928 AMC 436 (EDNY 1927).

715. The Whiz v Cram, 23 F2d 485 (5th Cir 1928).

716. Cooley v Standard Oil Co of La, 17 F2d 950 (ED La 1927), affd, 1928 AMC 586 (5th Cir 1928).

717. Transmarine Corp v Steamtugs JC Hartt ↔) Senator Rice, 1928 AMC 560 (EDNY 1928).

718. Pfeil v SS Wampum, 1928 AMC 1579 (EDNY 1928).

719. US Mexican Transp, Inc v United States, 1928 AMC 1362 (EDNY 1928).

720. Huasteca Petroleum Co v United States, 27 F2d 734 (2d Cir 1928).

721. In re The Black Sea Ship «) Oil Co, 1929 AMC 138 (SDNY 1929).

722. The Elkridge, 24 F2d 147 (SDNY 1927), modified, 30 F2d 618 (2d Cir 1929).

723. Carlo Marino v Trawler Maritima, 1929 AMC 355 (D Mass 1929).

724. Royal Neth SS Co v Schooner Fearless, 1929 AMC 489 (D PR 1929).

725. Portland Trawling Co v Schooner Gerbeviller, 1929 AMC 1660 (D Mass 1929).

726. Mountain Oil et Refining Co v Bronx Barge Corp No 1, 1929 AMC 1626 (EDNY 1929).

727. Lone Star SS Co v SS Susherico, 1929 AMC 1351 (EDNY 1929).

728. OJT Towing « Transp Co v Steamtug Eugene F Moran, 1929 AMC 1782 (SDNY 1929).

729. Petterson $v$ Steamtug Flannery Line, 1930 AMC 612 (EDNY 1930).

730. Atl Transp Co v United States, 1930 AMC 726 (Ct Cl 1930).

731. Strachan Shipping Co $v$ Cities Serv Refining Transp Co (The Shreveport), 42 F2d 524 (D SC 1930).

732. Motor Tug Viking No II v Diesel Tug NY Cent No 33, 1930 AMC 1487 (EDNY 1930).

733. S Pac SS Co v New Orleans Coal « Bisso Towboat Co, 43 F2d 177 (ED La 1930). 
734. Munson SS Line v SS Lake Treba, 1930 AMC 2038 (SD Fla 1930).

735. The Pelotas, 1930 AMC 1795 (ED La 1930).

736. Mason v SS Crampton Anderson, 1931 AMC 43 (EDNY 1930).

737. Schweigel v Scow George B Barnes, 1931 AMC 502 (EDNY 1931).

738. Curry v SS Kekoskee, 1931 AMC 705 (WD Wash 1931).

739. In re Atl Gulf e) W Indies SS Lines, 49 F2d 263 (2d Cir 1931).

740. Rice v Bakovic (The Star), 53 F2d 890 (WD Wash 1931).

741. Standard Transp Co v Scows Rufus T Gent ↔) Greystone, 1931 AMC 1795 (EDNY 1931).

742. Grosvold v Power Schooner Commonwealth, 1932 AMC 199 (WD Wash 1931).

743. Pisctaqua River Towing Co v United States, 1932 AMC 351 (D Mass 1932).

744. Steamtug Dr George I Moser, Inc v SS William Rockefeller, 1932 AMC 249 (2d Cir 1932), revg, 1931 AMC 1228 (EDNY 1931).

745. Harold Nesland v SS Northwestern, 1932 AMC 718 (WD Wash 1932).

746. Richfield Oil v Curry, 55 F2d 875 (9th Cir 1931), affg, 47 F2d 235 (WD Wash 1931).

747. Hubble Towing Co v Charles R McCormick Lumber Co (The Wahkeena), 56 F2d 833 (WD Wash 1931), modified, 1932 AMC 556 (9th Cir 1932).

748. Huasteca Petroleum Co v 27,907 Bags of Coffee, 60 F2d 907 (2d Cir 1932).

749. Doane-Commercial Towing Co v SS Saguache, 1932 AMC 1323 (D Mass 1932).

750. Harbor Tow Boat Co v Motor Boat Kiki (The Kiki), 1933 AMC 567 (EDNY 1933).

751. Gabelich v Diesel Vessel Patria, 1934 AMC 147 (SD Cal 1933).

752. Trimount Dredging Co v Motorship Clevelander, 1933 AMC 1557 (EDNY 1933).

753. Newtown Creek Towing Co v Steamtugs Roger C Sullivan, 1934 AMC 332 (SDNY 1934).

754. United States v SS Ansaldo San Giorgio Secondo, 1934 AMC 360 (2d Cir 1934), modifying 1933 AMC 181 (SDNY 1933).

755. Edward Card Co v SS Fred Weller, 1935 AMC 224 (EDNY 1934).

756. Frakich v Motor Boat Japonica, 1935 AMC 480 (SD Tex 1935). 
757. AH Bull SS Co v Bouchard Transp Co,1935 AMC 489 (EDNY 1935).

758. Dalzell v Cent Union Stockyards Co (The Dalzellea), 12 F Supp 179 (SDNY 1935).

759. Am S African Line, Inc v Dampk-Selsk-Svenborg (The Eastern Glen), 11 F Supp 995 (SDNY 1935).

760. Jacobus-Grauwiller Co v Tug Charles Beckwith III, 1936 AMC 317 (SDNY 1936).

761. Slayne v Consul Fuel Corp (The Mary S), 17 F Supp 72 (EDNY 1936).

762. The Caleb Haley, 9 Alaska 110 (D Alaska 1937).

763. Roy Shorts v Dravo Construction Co, 1938 AMC 57 (ED Pa 1937).

764. Steel Barge No 105 v Griffin, 1938 AMC 957 (5th Cir 1938).

765. Pac Salvage Co v Italian Ship Feltre, 1939 AMC 1173 (D Or 1939).

766. Radisic v Am Diesel, 1940 AMC 1017 (ND Cal 1940).

767. Costanzo Transp Co v Am Barge Line, 1940 AMC 1382 (WD Pa 1940).

768. Atl Towing Co v The Caliche, 47 F Supp 610 (SD Ga 1942).

769. Atl Towing Co v The Egbert H, 44 F Supp 656 (SD Ga 1942), modified, 131 F2d 111 (5th Cir 1942).

770. Rustad v Wuori (The Melody), 157 F2d 448 (9th Cir 1946).

771. The Donbass, 74 F Supp 15 (WD Wash 1947).

772. The Fairisle, 76 F Supp 27 (D Md 1947), affd, 171 F2d 408 (4th Cir 1948).

773. Kittelsaa $v$ United States, 1948 AMC 500 (EDNY 1948).

774. The Fearless, 76 F Supp 959 (SD Cal 1948).

775. The Angie \&) Florence, 77 F Supp 404 (D Mass 1948).

776. The Omaha, 71 F Supp 314 (DPR 1947), affd in part, Hamburg-Am Line v United States, 168 F2d 47 (1st Cir 1948).

777. Broere v Two Thousand One Hundred Thirty-Three Dollars, 78 F Supp 635 (EDNY 1948).

778. Burns Bros v Erie RR Co, 1948 AMC 1161 (EDNY 1948).

779. Waterman SS Corp v Dean, 171 F2d 408 (4th Cir 1948).

780. Kovell v Portland Tug e) Barge Co, 1949 AMC 380 (9th Cir 1948), modifying 1948 AMC 877 (ND Cal 1948).

781. Great Lakes Dredge « Dock Co v Metro Sand «) Gravel Corp, 1949 AMC 449 (EDNY 1949).

782. Joncich $v$ Xitco, 172 F2d 1003 (9th Cir 1949).

783. Dee $v$ United States, 1949 AMC 1181 (SDNY 1949).

784. Breving $v$ The Lloyd Cuarto, 84 F Supp 33 (ND Cal 1949).

785. Crescent Towing et Salvage Co v The MV 117, 87 F Supp 257 (ED La 1949). 
786. Higgins, Inc $v$ The Motor Vessel Tri-State, 1951 AMC 862 (SD Fla 1951).

787. Baretich $v$ United States, 97 F Supp 600 (SDNY 1951).

788. Burke v United States, 96 F Supp 335 (SDNY 1951).

789. Puget Sound Tug «) Bargo Co v Waterman SS Corp, 98 F Supp 123 (ND Cal 1951).

790. Schroeder v United States, 1951 AMC 1906 (SDNY 1951).

791. Danner v United States, 99 F Supp 880 (SDNY 1951).

792. Squires v SS Ionian Leader, 1952 AMC 161 (D NJ 1951).

793. Kell v Zermatten, 101 F Supp 898 (SD Cal 1952).

794. Haugen $v$ The Cape Karluk, 107 F Supp 34 (WD Wash 1952).

795. Shipowner's « Merchants Towboat Co v United States, 1955 AMC 2312 (D Or 1952).

796. Cuttyhunk Boat Lines v F/V Mary J Hayes, 1953 AMC 812 (D Mass 1953).

797. Hendry Corp v Aircraft Rescue Vessels, C-77436 and C77439, 113 F Supp 198 (ED La 1953).

798. Kimes $v$ United States, 207 F2d 60 (2d Cir 1953).

799. In re Esso Shipping Co, 122 F Supp 133 (SD Tex 1954).

800. Rauch $v$ Gulf Refining Co, 129 F Supp 843 (ED La 1955).

801. Lago Oil e) Transp Co v United States, 1953 AMC 2037 (SDNY 1953), revd, remanded, 218 F2d 631 (2d Cir 1955), modified, 1956 AMC 544 (2d Cir 1956), modified, 156 AMC 841 (2d Cir 1956).

802. Indian Towing Co v Miss Valley Barge Line Co, 1955 AMC 2035 (ED La 1955), affd, 232 F2d 750 (5th Cir 1956).

803. Devine v United Transp, 1957 AMC 175 (WD Wash 1956).

804. Lykes Bros SS Co v The Flying Boat N-31235, 1957 AMC 1957 (SD Cal 1957).

805. Kacprzynski v Lenhart, 1957 AMC 1121 (D Conn 1957).

806. Powers $v$ White (The Snow Maiden), 155 F Supp 518 (D Mass 1957), vacated, 159 F Supp 30 (D Mass 1958).

807. The Judith Lee Rose $v$ The Clipper, 169 F Supp 885 (D Mass 1959).

808. Nicastro $v$ The Peggy B, 173 F Supp 61 (D Mass 1959).

809. Nolan $v$ Aktieselskab, 164 F Supp 774 (ED Pa 1958), modified, 267 F2d 584 (3d Cir 1959).

810. Brady $v$ The SS African Queen, 179 F Supp 321 (ED Va 1960).

811. Beach Salvage Corp of Fla v The Shrimp Boat Cap't Tom, 201 F Supp 479 (SD Fla 1961).

812. Dominguez v Schooner Brindicante, 204 F Supp 817 (D PR 1962).

813. The DiGirolamo v C Malone Trucking, Inc, 211 F Supp 660 (D Mass 1962). 
814. Oil Screw Noah's Ark v Bentley ef Felton Corp, 1964 AMC 59 (5th Cir 1963) revg 1963 AMC 271 (SD Fla 1962).

815. Petition of United States, 229 F Supp 241 (D Or 1963).

816. Tampa Tugs « Towing, Inc v M/V Sandanger, 242 F Supp 576 (SD Cal 1965).

817. WE Rippon e) Son $v$ United States, 1964 AMC 2695 (SDNY 1963), affd, 348 F2d 627 (2d Cir 1965).

818. Nicholas E Vernicos Shipping \&) Co v United States, $223 \mathrm{~F}$ Supp 116 (SDNY 1963), modified, 349 F2d 465 (2d Cir 1965).

819. Dize v Steel Barge Beverley, 247 F Supp 968 (ED Va 1965).

820. Smith $v$ Union Oil Co, 1967 AMC 1097 (WD Wash 1966).

821. Id, 1967 AMC 1097.

822. Medina $v$ One Nylon Purse Seine, 259 F Supp 769 (SD Cal 1966).

823. Fred Devine v F/V Hornet, 1969 AMC 640 (D Alaska 1967).

824. Sobonis v Steam Tanker Natl Defender, 298 F Supp 631 (SDNY 1969).

825. Conolly v SS Karina II, 302 F Supp 675 (EDNY 1969).

826. Star Towing Co v The Barge ORG-6504, 301 F Supp 819 (ED La 1969).

827. In re Yamashita-Shinnihon Kisen, 1969 AMC 2102 (D Or 1969).

828. Id, 1969 AMC 2102.

829. United States $v$ Am Oil Co (In re Am Oil Co), 417 F2d 164 (5th Cir 1969).

830. Seaman $v$ Tank Barge OC601, 325 F Supp 1206 (SD Ala 1971).

831. Lancaster $v$ Smith, 330 F Supp 65 (SD Ala 1971).

832. Sears v SS Am Producer, 1972 AMC 1647 (ND Cal 1972).

833. Nadle $v$ M/V Tequila, 1974 AMC 860 (SDNY 1974).

834. St Paul Marine Transp Corp v Cerro Sales Corp, 505 F2d 1115 (9th Cir 1974).

835. Puamier v Barge BT 1793, 395 F Supp 1019 (ED Va 1974).

836. Legnos $v$ M/V Olga Jacob, 1975 AMC 1585 (MD Fla 1975).

837. Anepac, Ltd v Barge Great Sound, 12 VI 128 (DVI 1975).

838. Franke1 v Dravo Corp, 1980 AMC 531 (DDC 1979).

839. Jackson $v$ Costa Lines, Inc, 490 F Supp 393 (SD Fla 1980).

840. SC Loveland Co v The Barge Arlington, 1982 AMC 704 (WD La 1980).

841. Tidewater Salvage, Inc v Weyerhaeuser Co, 633 F2d 1304 (9th Cir 1980).

842. Markakis $v$ S/S Veendam, 1981 AMC 2275 (SDNY 1981).

843. Vinco Enterp v NY Dock Ry, 540 F Supp 1183 (EDNY 1982).

844. Cobb Coin Co v Unidentified, Wrecked \& Abandoned Shipping Vessel, 549 F Supp 540 (SD Fla 1982). 
845. Treasure Salvors, Inc v Unidentified, Wrecked «) Abandoned Sailing Vessel, 556 F Supp 1319 (SD Fla 1983).

846. Platoro Ltd v Unidentified Remains of a Vessel, 518 F Supp 816 (WD Tex 1981), affd in part, vacated in part, modified, 695 F2d 893 (5th Cir 1983).

847. BV Bureau Wijsmuller $v$ United States, 487 F Supp 156 (SDNY 1979), affd, 702 F2d 333 (2d Cir 1983).

848. McNabb v OS Bowfin, 565 F Supp 22 (WD Wash 1983).

849. Reynolds Leasing Corp $v$ The Tug Patrice McAllister, $572 \mathrm{~F}$ Supp 1131 (SDNY 1983).

850. In re Ta Chi Nav (Pan) Corp SA, 1985 AMC 1367 (SDNY 1984).

851. SF Bar Pilots $v$ The Vessel Peacock, 733 F2d 680 (9th Cir 1984).

852. Bindon $v$ Jones, 1986 AMC 1403 (WD Wash 1984).

853. Unnamed But Identifiable Master « Crew of that Certain US Documented Vessel Bearing Doc No 567135 v Unnamed Motor Vessel Bearing Fla Reg No FL5607, 592 F Supp 1191 (SD Fla 1984).

854. US Dominator, Inc v Factory Ship Robert E Resoff, 768 F2d 1099 (9th Cir 1985).

855. Kuhr v Sea-Alaska Prods, 1986 AMC 2299 (WD Wash 1985).

856. Allseas Mar, SA v M/V Mimosa, 812 F2d 243 (5th Cir 1987) rehg denied, 820 F2d 129 (5th Cir 1987).

857. Hernandez $v$ Roberts, 675 F Supp 1329 (SD Fla 1988).

858. Hendricks $v$ The Tug Gordon Gill, 737 F Supp 1099 (D Alaska 1989).

859. Jackson Marine Corp v M/V Blue Fox, 1989 WL 38724 (ED La 1989).

860. Brown $v$ Johansen, 881 F2d 107 (4th Cir 1989).

861. Flagship Marine Servs, Inc v Belcher Towing Co, 761 F Supp 792 (SD Fla 1991), revd on other grounds, 966 F2d 602 (11th Cir 1992).

862. Osal Marine Servs, Inc, v M/V Panasea, 1993 AMC 1930 (WD Wash 1992).

863. Ocean Servs Towing e) Salvage, Inc v Brown, 810 F Supp 1258 (SD Fla 1993).

864. Taylor v 42 Foot Egg Harbor Hull, 1995 AMC 582 ( D NJ 1994).

865. Monica Lynn, Inc v Triton 4, 36 F3d 90 (5th Cir 1994).

866. Columbus-Am Discovery Grp v Atl Mut Ins Co, 56 F3d 556 (4th Cir 1995), affg \&) remanding, 1993 WL 580900 (ED Va 1993).

867. HRM, Inc v S/V Eagle Light, 1997 AMC 1972 (D Conn 1997). 
868. Falgout Bros, Inc v S/V Pangaea, 966 F Supp 1143 (SD Ala 1997).

869. HRM, Inc $v$ S/V Venture VII, 972 F Supp 92 (DRI 1997).

870. Margate Shipping Co v M/V JA Orgeron, 143 F3d 976 (5th Cir 1998).

871. United States V Ex-USS Cabot/Dedalo, 179 F Supp 2d 697 (SD Tex 2000), revd on other grounds, 297 F3d 378 (5th Cir 2002).

872. Bartholomew v Crowley Marine Servs, Inc, 2002 AMC 1547 (WD Wash 2002), affd in part, revd in part, 337 F3d 1083 (9th Cir 2003).

873. New Bedford Marine Rescue, Inc, v Cape Jeweler's Inc, 240 F Supp 2d 101 (D Mass 2003).

874. Biscayne Towing $\uplus$ Salvage, Inc v Kilo Alfa, Ltd, 2005 AMC 129 (SD Fla 2004).

875. Atlantis Marine Towing, Inc $v$ The $M / V$ Elizabeth, $346 \mathrm{~F}$ Supp 2d 1266 (SD Fla 2004).

876. Reiss $v$ One Schat-Harding Lifeboat, 444 F Supp 2d 553 (D SC 2006).

877. Joseph $v$ JP Yachts, LLC, 436 F Supp 2d 254 (D Mass 2006).

878. Triplecheck, Inc $v$ Creole Yacht Charters Ltd, 2007 WL 917276 (SD Fla 2007).

879. Miami Yacht Drivers, Inc v M/V All Access, 2008 AMC 170 (SD Fla 2007).

880. Sea Tow Portland/Vancouver v High Steaks, 2007 AMC 2705 (D Or 2007).

881. Boat Raising et Reclamation $v$ Victory, 2007 WL 4462995 (MD Fla 2007). 